\title{
Wind Power and Public Engagement
}

Adopting an interdisciplinary social science approach, this book examines community reactions to wind farms to form a new understanding of what facilitates social acceptance.

Based on empirical research, Wind Power and Public Engagement investigates opposition to wind energy and considers the advantages as well as the limits of the co-operative model of wind farm community ownership. Giuseppe PellegriniMasini compares the role of co-operative schemes with community benefits schemes in increasing acceptability, and also sheds light on the impact of social factors including pro-environmental attitudes, perceived benefits and costs, place attachment, trust, as well as individuals' resources such as information and income. Five research cases are investigated in England and Scotland, including the first local, community-owned wind farm co-operative in the UK. Critically reviewing existing social research theories, the book offers a new viewpoint, integrating rational choice and environmental attitudinal theories, from which to assess and understand the social acceptability of wind energy. It also highlights new opportunities for raising consensus in communities around locally proposed wind farms.

The book will be of great interest to students and scholars of renewable energy, energy policy, environmental sociology, environmental psychology, environmental planning and sustainability in general, as well as policymakers.

Giuseppe Pellegrini-Masini is a Postdoctoral Fellow in the Department of Psychology at the Norwegian University of Science and Technology (NTNU), Norway, and a Research Affiliate in the Research Area in Public Ethics at the Sant'Anna School of Advanced Studies, Italy. He holds a PhD from the School of Energy, Geoscience, Infrastructure and Society at Heriot-Watt University, Scotland. 


\section{Routledge Studies in Energy Policy}

\section{Guanxi and Local Green Development in China}

The Role of Entrepreneurs and Local Leaders

Chunhong Sheng

Energy Policies and Climate Change in China

Actors, Implementation and Future Prospects

Han Lin

Energy Efficiency in Developing Countries

Policies and Programmes

Suzana Tavares da Silva and Gabriela Prata Dias

Ethics in Danish Energy Policy

Edited by Finn Arler, Mogens Rüdiger, Karl Sperling,

Kristian Høyer Toft and Bo Poulsen

Mainstreaming Solar Energy in Small, Tropical Islands

Cultural and Policy Implications

Kiron C. Neale

Appraising the Economics of Smart Meters

Costs and Benefits

Jacopo Torriti

Wind Power and Public Engagement

Co-operatives and Community Ownership

Giuseppe Pellegrini-Masini

Social Movements against Wind Power in Canada and Germany

Energy Policy and Contention

Andrea Bues

For further details please visit the series page on the Routledge website: www. routledge.com/books/series/RSIEP/ 


\section{Wind Power and Public Engagement Co-operatives and Community Ownership}

Giuseppe Pellegrini-Masini

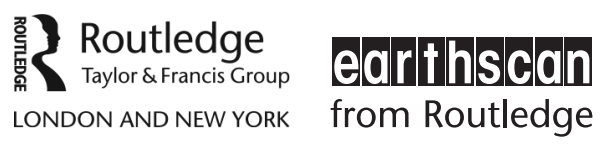


First published 2020

by Routledge

2 Park Square, Milton Park, Abingdon, Oxon OX14 4RN

and by Routledge

52 Vanderbilt Avenue, New York, NY 10017

Routledge is an imprint of the Taylor \& Francis Group, an informa business

(c) 2020 Giuseppe Pellegrini-Masini

The right of Giuseppe Pellegrini-Masini to be identified as author of this work has been asserted by him in accordance with sections 77 and 78 of the Copyright, Designs and Patents Act 1988.

All rights reserved. No part of this book may be reprinted or reproduced or utilised in any form or by any electronic, mechanical, or other means, now known or hereafter invented, including photocopying and recording, or in any information storage or retrieval system, without permission in writing from the publishers.

Trademark notice: Product or corporate names may be trademarks or registered trademarks, and are used only for identification and explanation without intent to infringe.

British Library Cataloguing-in-Publication Data

A catalogue record for this book is available from the British Library

Library of Congress Cataloging-in-Publication Data

A catalog record has been requested for this book

ISBN: 978-1-138-58910-0 (hbk)

ISBN: 978-0-429-49189-4 (ebk)

Typeset in Times New Roman

by Wearset Ltd, Boldon, Tyne and Wear 


\section{Contents}

List of figures vi

List of tables $\quad$ ix

Acknowledgements xiii

Foreword xiv

CHRISTIAN A. KLÖCKNER

Introduction 1

1 Citizens and renewable energy: determinants of civic engagement

2 Wind energy acceptability - what, how and when: all the variables at stake

3 Testing the theory: methods and data collection 67

4 The first community-owned co-operative in the UK: lessons from Westmill Wind Farm

5 A survey of four Scottish proposed wind farms

6 A theory of social acceptability of wind farms: finding a place for the co-operative model

Conclusions

Appendix A: the postal survey questionnaire 


\section{Figures}

2.1 Theoretical framework of wind farm acceptance and participation in community co-operative scheme

5.1 Level of education declared

5.2 Responses to the question: "Is electricity produced by wind turbines cheaper or more expensive to produce than electricity produced by other means such as coal-fired power stations?"

5.3 Responses to the question: "Whatever the location, do wind turbines produce a steady stream of electricity?"

5.4 Responses to the question: "Are you aware that the [...] wind farm has been proposed in your local area?"

5.5 Responses to the question: "Can you see from your home $[\ldots]$, the site of your proposed local wind farm?"

5.6 Responses to the question: "Can you see from your home [...], the site of your proposed local wind farm?"- -by area surveyed

5.7 Frequency of seeing the wind farm site among respondents who cannot see the wind farm from home

5.8 Responses to the question: "What do you think of the presence of this wind farm in your area?"

5.9 Perceived environmental responsibility and level of action 136

5.10 Preferences between prioritising economic growth and environmental protection

5.11 Responses to the statement: "I like how my area looks" 138

5.12 Responses to the statement: "I like my community" 138

5.13 Responses to the statement asking whether the wind farm will bring local benefits or disadvantages

5.14 Responses to the statement: "The wind farm will harm the health of my community"

5.15 Responses to the statement: "The wind farm will help to fight climate change"

5.16 Responses to the statement: "The wind farm will look bad on the landscape"

5.17 Responses to the statement: "The wind farm will improve the local economy" 
5.18 Responses to the statement: "The wind farm will bring down the local property prices"

5.19 Responses to the statement: "The wind farm will attract tourists"

5.20 Responses to the statement: "The wind farm will be unpleasantly noisy"

5.21 Responses to the statement: "The wind farm will generate costlier electricity than if it was generated by ordinary fuel"

5.22 Responses to the statement: "The wind farm will help to free the country from dependence on foreign fuels"

5.23 Responses to the statement: "I trust the developers of the wind farm in the way they deal and have dealt with the local community"

5.24 Responses to the statement: "I feel that I have been thoroughly informed about the wind farm"

5.25 Responses to the statement: "The co-operative will just be a ploy to buy residents' consensus"

5.26 Responses to the statement: "The co-operative will give locals the chance to benefit from the revenue of the wind farm"

5.27 Responses to the statement: "The co-operative will create a permanent divide in the local community between those who would join and those who would oppose the wind farm"

5.28 Responses to the statement: "The co-operative will persuade those who are undecided to support the wind farm"

5.29 Responses to the statement: "The co-operative will offer the worst compensation for those who oppose the wind farm because their decision not to join means they will not receive any revenue"

5.30 Responses to the statement: "The co-operative will involve local people not only financially but also in its management: it will create a stable network of local residents who might support further community activities and projects"

5.31 Responses to the statement: "The co-operative will persuade even opponents of the wind farm to accept the development"

5.32 Responses to the statement: "The co-operative will not make any difference. People will support or oppose the wind farm regardless of whether there is a co-operative scheme or not"

5.33 Responses to the statement: "I think that it would be a good investment opportunity"

5.34 Responses to the statement: "I oppose the wind farm so I would never join in" 
viii Figures

5.35 Responses to the statement: "I believe that we all should do something to fight climate change, therefore I would join"

5.36 Responses to the statement: "I couldn't afford to buy share"

5.37 Responses to the statement: "If people around me, in my community, would support it, so would I"

5.38 Responses to the statement: "I don't care about the wind farm and so I would not care about the co-operative"

5.39 Responses to the statement: "I would be able to have a say in the development of the wind farm and its management"

5.40 Responses to the question: "All in all, what do you think of a 'community wind farm co-operative'?"

5.41 Responses to the question: "If you could choose ONE of the schemes that we have presented for your local wind farm, which one would you choose?" 


\section{Tables}

3.1 Cases chosen for the quantitative postal survey 72

4.1 Expected landscape attributes following the construction of Westmill Wind Farm

4.2 Costs and benefits identified in the case of Westmill Wind Farm Co-operative

5.1 Distribution of respondents across surveyed sites 123

5.2 Level of education declared and wind farm sites 125

5.3 Gross household income declared in British pounds (GBP) 126

5.4 Declared household income by wind farm site 127

5.5 Awareness of the proposed community scheme for the local wind farm

5.6 Opinion regarding the locally proposed wind farm across surveyed sites

5.7 Motives for opinions of supporters of the locally proposed wind farm

5.8 Motives for opinions of undecided about the locally proposed wind farm

5.9 Motives for opinions of opponents of the locally proposed wind farm

5.10 Cross tabulation between the variables "opinion about the locally proposed wind farm" and "name of the wind farm" 156

5.11 Chi-square tests 157

5.12 Symmetric measures 157

5.13 Correlations between "residents' distance from the proposed site" and "opinion about the locally proposed wind farm"

5.14 Correlations between "opinion about the proposed wind farm" and "social context deprived/affluent"

5.15 Correlations between "opinion about the proposed wind farm" and "socialcontext2"

5.16 Cross tabulation between the variables "presence of opinion" and "socialcontext2" 
$\begin{array}{ll}5.18 \text { Symmetric measures } & 160\end{array}$

5.19 Correlations between "opinion about the proposed wind farm" and "level of education"

5.20 Correlations between "opinion about the proposed wind farm" and "number of household members"

5.21 Correlations between "opinion about the proposed wind farm" and "household income"

5.22 Correlations between "opinion about the proposed wind farm" and "estimation of income per family member"

5.23 Correlations between "opinion about the proposed wind farm" and "knowwind"

5.24 Correlations between "opinionwf3items" and "knowwind"

5.25 Cross tabulation between the variables "opinion about the locally proposed wind farm" and "awareness of the proposed wind farm"

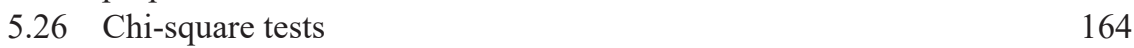

$\begin{array}{lll}5.27 & \text { Symmetric measures } & 164\end{array}$

5.28 Cross tabulation between the variables "opinionwf3items" and "seeing the wind farm site from home"

$\begin{array}{ll}5.29 \text { Chi-square tests } & 166\end{array}$

$\begin{array}{lll}5.30 & \text { Symmetric measures } & 166\end{array}$

5.31 Correlations between "opinion about the proposed wind farm" and "how often see the wind farm site"

5.32 Correlations between "opinionwf3items" and "how often see the wind farm site"

5.33 Cross tabulation between the variables "opinionwf3items" and "awarescheme3"

$\begin{array}{ll}5.34 \text { Chi-square tests } & 167\end{array}$

$\begin{array}{lll}5.35 & \text { Symmetric measures } & 168\end{array}$

5.36 Correlations between "opinion about the wind farm" and "local benefits/disadvantages"

5.37 Correlations between "opinion about the wind farm" and "wind farm harms local health"

5.38 Correlations between "opinion about the wind farm" and "wind farm helps climate change"

5.39 Correlations between "opinion about the wind farm" and "wind farm looks bad on the landscape"

5.40 Correlations between "opinion about the wind farm" and "wind farm improves the local economy"

5.41 Correlations between "opinion about the wind farm" and "wind farm bring down property prices"

5.42 Correlations between "opinion about the locally proposed wind farm" and "wind farm attracts tourists" 
5.43 Correlations between "opinion about the locally proposed wind farm" and "wind farm is noisy"

5.44 Correlations between "opinion about the locally proposed wind farm" and "wind farm generates costlier electricity"

5.45 Correlations between "opinion about the locally proposed wind farm" and "wind farm helps with fuel dependency"

5.46 Correlations between "opinion about the locally proposed wind farm" and "benefitscostsvalue"

5.47 Correlations between "benefitscostsvalue" and "knowwind"

5.48 Correlations between "benefitscostsvalue" and "estimation of income per family member"

5.49 Correlations between "benefitscostsvalue" and "level of education"

5.50 Cross tabulation between the variables "opinionwf3items" and "environmental citizenship level"

5.51 Chi-square tests

5.52 Symmetric measures

5.53 Correlations between "opinion about the locally proposed wind farm" and "environment vs economy trade-off"

5.54 Correlations between "opinion about the locally proposed wind farm" and "place attachment2"

5.55 Correlations between "opinion about the locally proposed wind farm" and "place attachment - physical place"

5.56 Correlations between "opinion about the locally proposed wind farm" and "place attachment-social place"

5.57 Correlations between "opinion about the proposed wind farm" and "trust towards developers"

5.58 Correlations between "opinion about the locally proposed wind farm" and "information about the wind farm"

5.59 Cross tabulation between the variables "opinion about the locally proposed wind farm" and "scheme of ownership co-op/commercial"

5.60 Chi-square tests

5.61 Symmetric measures

5.62 Correlations between "opinion about the locally proposed wind farm" and "co-operative scheme opinion"

5.63 Cross tabulation between the variables "decision to invest" and "opinion about the locally proposed wind farm"

5.64 Chi-square tests

5.65 Symmetric measures

5.66 Correlations between "opinion about the locally proposed wind farm" and "co-operative idea opinion"

5.67 Cross tabulation between the variables "scheme of choice" and "opinionwf3items" 
xii Tables

$\begin{array}{lll}5.68 & \text { Chi-square tests } & 183\end{array}$

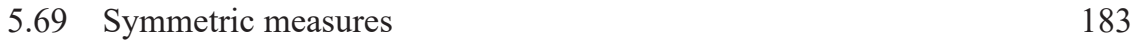

5.70 Summary of significant correlations with the variable

$\begin{array}{ll}5.71 \text { Model fitting information } & 186\end{array}$

$\begin{array}{ll}5.72 \text { Goodness of fit } & 187\end{array}$

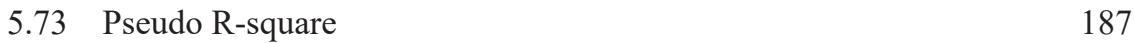

$\begin{array}{lll}5.74 & \text { Test of parallel lines } & 188\end{array}$

$\begin{array}{ll}5.75 & 189\end{array}$

$\begin{array}{ll}5.76 \text { Model fitting information } & 190\end{array}$

$\begin{array}{ll}5.77 \text { Pseudo R-square } & 191\end{array}$

$\begin{array}{ll}5.78 \text { Test of parallel lines } & 191\end{array}$

$\begin{array}{ll}5.79 \text { Parameter estimates } & 192\end{array}$

$\begin{array}{lll}5.80 & \text { Dependent variable encoding } & 194\end{array}$

$\begin{array}{ll}5.81 \text { Omnibus tests of model coefficients } & 195\end{array}$

$\begin{array}{ll}5.82 \text { Model summary } & 195\end{array}$

$\begin{array}{ll}5.83 \text { Hosmer and Lameshow test } & 195\end{array}$

$\begin{array}{ll}5.84 \text { Classification table } & 196\end{array}$

$\begin{array}{ll}5.85 & \text { Variables in the equation } \\ & 196\end{array}$ 


\section{Acknowledgements}

I wish, above all, to thank Professor Phillip Frank Gower Banfill of Heriot-Watt University, without whose enduring support this work would not have been completed. He demonstrated to me the most important skills that a supervisor should possess: respect, trust and empathy. I also thank my family, my friends and my colleagues for the support and advice they gave me at various times during the years when I was working on this project. Finally, I wish to thank Professor Christian A. Klöckner in the Department of Psychology at Norwegian University of Science and Technology (NTNU), who saw the merits of this work and lent his time to write the Foreword.

This research was carried out thanks to the support of the following projects: EPSRC SUPERGEN "Future Network Technologies", EPSRC TARBASE "Technology Assessment for Radically Improving the Built Asset base", and Horizon 2020 SMARTEES "Social Innovation Modelling Approaches to Realizing Transition to Energy Efficiency and Sustainability", grant agreement No 763912. 


\section{Foreword}

When the United Nations Sustainable Development Goals were accepted by the General Assembly of the UN in 2014 the world community committed to a list of seventeen common goals, to be reached by 2030. This included goals such as the ending of poverty, affordable and clean energy, reducing inequality, gender equality, sustainable cities and communities, responsible consumption and production and climate action. To reach these goals, a change in the way energy is produced and consumed in both established and upcoming economies is of crucial importance; the energy system is the backbone of our societies. The centralised energy systems that drove the industrial revolution in Western and Eastern economies in the twentieth century have clearly reached their limits. New organisational structures need to be found to tackle the challenges of the future, including a high degree of regenerative (and often unstable) energy sources, decentralisation of energy production, a much more active role for energy consumers and a complete shift in the roles of actors in the energy system.

These substantial changes in established systems are at the very basis of what actors expect from themselves and each other in these systems. Thus, the question of how to master these transitions is not so much technological or economic, but rather a question of understanding (local) cultures, practices, values and social rules. The psychology of decision makers at all levels moves into the focus of analysis, so we are able to understand potential facilitators or barriers in these transition processes.

With only ten years to go before we must reach the Sustainable Development Goals, and also only one decade left to limit global climate change to "substantially below 2 degrees" by implementing massive cuts in $\mathrm{CO}_{2}$ emissions, speeding up the energy transition is essential. This book highlights the new complexity of energy decisions through a comprehensive analysis of community wind farm co-operatives in the United Kingdom. It goes way beyond analysing ecological, economic and technical challenges and focuses on what co-operative models of energy production contribute to social sustainability, energy justice or democratisation of the energy system. This has clear impacts on the acceptability of energy projects that can have an invasive character in local communities, such as onshore wind parks. 
The empirical work behind this book shows that community-driven energy production moves the focus from purely economic evaluations to include a more diverse set of criteria, balancing economy with negative local effects on nature or health with benefits for the global climate and considerations for alleviating fuel dependency. Those engaged in creating local co-operatives obviously consider a large set of local to global costs and benefits, which makes their judgments potentially more acceptable for local communities than decisions made by external commercial actors. A key benefit of co-operative forms of energy production for local communities seems to be that it offers community members the option of influencing operations rather than just benefitting (or suffering) from such implementation. Co-operative production thus gives community members stronger agency.

Although it appears that co-operative energy production is a viable way to greater engagement of local communities in the energy transition, it is not a silver bullet that will solve all the issues that arise with the necessary restructuration. From a bigger picture perspective, it is also interesting to interpret the results of this work concerning energy justice questions, especially distributional and procedural justice. Are co-operative energy producers per se more trustworthy with respect to just distribution of energy or revenues? Do they guarantee more just procedures in implementing projects? The Conclusions of this book analyse such questions from a policy-making perspective. Wind Power and Public Engagement thus makes a valuable contribution to some of the biggest challenges our societies have to face in the coming ten years - enabling communities to make fast and substantial changes.

Christian A. Klöckner

Professor in Social Psychology and Quantitative Methods Norwegian University of Science and Technology 


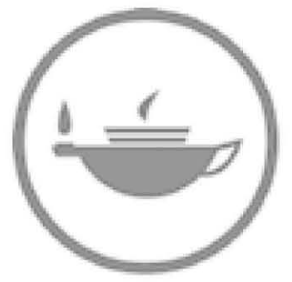

Taylor \& Francis Taylor \& Francis Group

http://taylorandfrancis.com 


\section{Introduction}

While the transition to a new energy system based on the wide deployment of renewables has become an undisputed necessity for our societies, many questions remain in terms of how energy should be delivered. Will nations and regions adopt policies that seek to maximise energy justice (Jenkins et al., 2017) and energy equality (Pellegrini-Masini, 2019) through diffused ownership of renewable energies? Or will they reproduce the concentrated ownership of the current energy production system?

Technologies such as solar photovoltaic, whose middle-class affordability has already been demonstrated, will most likely play a role in the energy transition towards an energy system centred on prosumerism. Yet this might not be the case for large solar plants, wind turbines or hydroelectric systems, all of which present substantial upfront costs that are a barrier to citizen ownership.

Still, the possibility for citizens to be part of the energy transition, not only as consumers but also as owners, is a significant step towards a more just energy system and one that reduces energy inequalities.

We know that energy consumption is largely unequal, not only across countries but also within them (Pachauri and Spreng, 2012). This trend reflects differences in income distribution, but it also reveals a vast problem with environmental equality and justice.

As the UN Human Rights Council (2019) has compellingly stated:

Perversely, the richest, who have the greatest capacity to adapt and are responsible for and have benefitted from the vast majority of greenhouse gas emissions, will be the best placed to cope with climate change, while the poorest, who have contributed the least to emissions and have the least capacity to react, will be the most harmed. The poorest half of the world's population- 3.5 billion people - is responsible for just 10 percent of carbon emissions, while the richest 10 percent are responsible for a full half. A person in the wealthiest 1 percent uses 175 times more carbon than one in the bottom 10 percent.

This situation will create a significant and challenging policy problem for years to come. Perpetuating this state of affairs would be at odds with the core values 


\section{Introduction}

of Western democracies and the procedural or formal equality principle that defines democratic systems and processes. Further, it would run counter to the substantive or distributional equality principle that is to some extent guaranteed by many democracies, whose constitutions provide for the right of citizens to satisfy their basic needs.

Recent conceptualisations of energy equality (Pellegrini-Masini, 2019) have argued for the need to establish greater equality of opportunity in using energy services and consuming energy or embodied energy. The desirability of greater "equality of opportunity" can be defended on both moral (Sen, 1980) and empirical (Wilkinson and Pickett, 2009) grounds. Egalitarian societies earn positive high rankings regarding many different quality-of-life indicators, ranging from health to crime to environmental care (Wilkinson and Pickett, 2009) and high-income countries appear to produce fewer emissions per capita (Jorgenson et al., 2015; Jorgenson et al., 2016; Knight et al., 2017). Despite some concern regarding the economic efficiency of egalitarian societies (Okun, 2015), recent research shows that high inequality negatively affects economic growth and that redistributive policies do not hinder growth (Cingano, 2014).

Arguably, the energy transition should not only deliver environmental sustainability but should also be economically and socially sustainable, thereby addressing energy inequality and delivering energy justice more broadly.

The goals of equitable, sustainable energy have already been put forward by European states, as the EU Commission (2019, p. 6) recently confirmed: "The clean energy transition must be fair and socially acceptable to all".

Community energy initiatives, particularly community wind farm co-operatives, are a way to contribute to a new economy of energy production in which prosumers (consumers who participate in the production process) are the norm rather than the exception. However, co-operatives are not devoid of challenges and can face similar obstacles to those experienced by other types of community energy initiatives. Specifically, community energy schemes risk creating a divide between individuals who have the financial means and the ability to join them and those who do not (Jenkins, 2019).

This book adopts an interdisciplinary social science approach to examine the factors that influence the acceptability of wind farms and wind farm co-operatives. Specifically, it addresses the following questions: What are the variables that influence participation in wind farm-co-operatives? Can wind farm co-operatives facilitate the acceptance of wind farm development at the pre-construction stage? How do co-operatives compare with other community wind farm schemes? What can be learned about the social acceptability of wind farms and renewable energy infrastructure more generally from previous research on the acceptability of wind farms and wind farm co-operatives? And finally, how might policy address resistance to renewable energy infrastructure?

Chapter 1 reviews the literature on citizen participation, activism, and proenvironmental behaviours that theoretically frame the extensive range of variables that affect participation in wind farm co-operatives. In fact, participation in a 
wind farm co-operative can be both a pro-environmental behaviour and a type of environmental activism.

Chapter 2 presents the specific variables that influence citizens' participation in wind farm co-operatives. Variables regarding types of perceived costs and benefits associated with wind farm siting, along with contextual and personal resource variables, are discussed. Further, the chapter examines co-operative schemes within the context of community energy schemes and their implications for wind farm acceptability. Finally, the theoretical framework that informed the empirical research presented in the book is outlined.

Chapter 3 presents the multimethod research design, based on a triangulation approach, along with details about the cases surveyed and the specific methods used.

Chapter 4 analyses interviews conducted with stakeholders of Westmill Wind Farm in Oxfordshire, Britain's first community-owned co-operative wind farm. The Westmill case provides compelling evidence on the strengths and the limits of the co-operative model, and reveals the profound impact that variables such as trust can have in shaping local debates and influencing levels of acceptability.

Many of the variables discussed in the analysis of the qualitative study also appear in Chapter 5, which presents the results of a multi-site survey conducted in four Scottish cases. The chapter provides a quantitative analysis of the wide range of variables, detailing how they correlate with the acceptability of proposed wind farms and their relative importance in influencing acceptability. It also examines additional variables regarding respondents' opinions about the co-operative model. The large number of variables surveyed (57) and their nature make this research distinctive, although they restricted the scope of the analysis to a limited range of statistical tests.

Chapter 6 discusses the survey results, examining the different groups of variables surveyed and, within each group, the specific variables that chiefly influenced opinions about the wind farm and the co-operative model. While some earlier assumptions about the role of pro-environmental attitudes are challenged, the chapter underlines the importance of perceived costs and benefits and, above all, "trust" as key determinants of the acceptability of wind farms.

While much can be said in support of co-operative wind farms and, to some extent, against them, this research shows that respondents were predominantly favourable towards wind farm co-operatives and to being offered the opportunity to participate in such a scheme, along with the provision of community benefits.

Certainly, community benefits are not a secondary issue. Instead of dismissing them as an unworthy policy provision of dubious morality, which could "crowd-out" environmental morale, it is time to advocate for a complementary approach (Frey, 1999) that strengthens pro-environmental attitudes and extrinsic motivations towards the goal of making onshore wind farms more acceptable. Such a pragmatic approach would be anything but immoral, not only because it would favour an overdue energy transition, but also because it could address issues of energy justice at various levels, including that of citizen compensation for facility siting (Corvino et al., 2019). 


\section{Introduction}

\section{References}

Cingano, F. 2014. Trends in income inequality and its impact on economic growth. OECD Social, Employment and Migration Working Papers. OECD Publishing, Paris.

Corvino, F., Pirni, A., Pellegrini-Masini, G. and Maran, S. 2019. Compensation for energy infrastructures: Can a capability approach be more equitable? Unpublished manuscript, Dirpolis Institute, Sant'Anna School of Advanced Studies, Pisa, Italy.

European Commission. 2019. Clean energy for all Europeans. Directorate-General for Energy, Luxembourg. Available at: https://publications.europa.eu/en/publicationdetail/-/publication/b4e46873-7528-11e9-9f05-01aa75ed71a1/language-en.

Frey, B. S. 1999. Morality and rationality in environmental policy. Journal of Consumer Policy, 22, 395-417.

Jenkins, K. E. H. 2019. Energy justice, energy democracy, and sustainability: Normative approaches to the consumer ownership of renewables. In: Lowitzsch, J. (ed.) Energy transition: Financing community co-ownership in renewables. Cham, Switzerland: Palgrave Macmillan.

Jenkins, K., McCauley, D. and Forman, A. 2017. Energy justice: A policy approach. Energy Policy, 105, 631-634.

Jorgenson, A. K., Schor, J. B., Huang, X. and Fitzgerald, J. 2015. Income inequality and residential carbon emissions in the United States: A preliminary analysis. Human Ecology Review, 22, 93-106.

Jorgenson, A. K., Schor, J. B., Knight, K. W. and Huang, X. 2016. Domestic inequality and carbon emissions in comparative perspective. Sociological Forum, 31, 770-786.

Knight, K. W., Schor, J. B. and Jorgenson, A. K. 2017. Wealth inequality and carbon emissions in high-income countries. Social Currents, 4, 403-412.

Okun, A. M. 2015. Equality and efficiency: The big tradeoff. Washington, DC: Brookings Institution Press.

Pachauri, S. and Spreng, D. 2012. Towards an integrative framework for energy transitions of households in developing countries. In: Spreng, D., Flueler, T., Goldblatt, D. L. and Minsch, J. (eds.) Tackling long-term global energy problems. Dordrecht, Netherlands: Springer.

Pellegrini-Masini, G. 2019. Energy equality and energy sufficiency: New policy principles to accelerate the energy transition. European Council for an Energy Efficient Economy 2019 Summer Study, "Energy efficiency first, but what next?", 3-8 June, Belambra Presqu'ile de Glens, France, 143-148.

Sen, A. 1980. Equality of what? In: McMurrin, S. M. (ed.) The Tanner lectures on human values. Cambridge: Cambridge University Press.

UN Human Rights Council. 2019. Climate change and poverty: Report of the special rapporteur on extreme poverty and human rights. United Nations, Geneva. Available at: https://srpovertyorg.files.wordpress.com/2019/06/unsr-poverty-climate-change-a hrc_41_39.pdf [Accessed 25 June 2019].

Wilkinson, R. G. and Pickett, K. 2009. The spirit level: Why greater equality makes societies stronger. New York: Bloomsbury Press. 
the long term, self-interest—which De Young (2000, p. 515) identifies as a form of "intrinsic satisfaction" - could keep a subject actively committed to a certain behaviour. De Young (2000, p. 521) holds the opinion that competence is a key aspect of intrinsic satisfaction: "People find unpleasant and thus avoid situations in which they cannot advance or utilize their competence."

\section{Final remarks about the literature on environmentally responsible behaviour}

The following conclusions can be drawn from the literature that has been reviewed on ERBs:

1 ERBs have different determinants depending on the kind of behaviour that we consider.

2 Different behaviours could share the same determinants, but the relative effect on influencing behaviours would vary from one kind of behaviour to another.

3 Information and environmental awareness alone are not able to predict ERBs.

4 Attitudes alone are insufficient to predict ERBs, but they have more predictive power when the considered behaviours do not incur costs from situational barriers and strong disadvantages (for example, money and time costs).

\section{References}

Bandura, A. 2000. Exercise of human agency through collective efficacy. Current Directions in Psychological Science, 9, 75-78.

Bandura, A. 2001. Social cognitive theory: An agentic perspective. Annual Review of Psychology, 52, 1-26.

Bandura, A. 2002. Selective moral disengagement in the exercise of moral agency. Journal of Moral Education, 31, 101-119.

Barnes, R., Auburn, T. and Lea, S. 2004. Citizenship in practice. British Journal of Social Psychology, 43, 187-206.

Barr, S. 2003. Strategies for sustainability: Citizens and responsible environmental behaviour. Area, 35, 227-240.

Batel, S., Devine-Wright, P. and Tangeland, T. 2013. Social acceptance of low carbon energy and associated infrastructures: A critical discussion. Energy Policy, 58, 1-5.

Batel, S., Devine-Wright, P., Wold, L., Egeland, H., Jacobsen, G. and Aas, O. 2015. The role of (de-)essentialisation within siting conflicts: An interdisciplinary approach. Journal of Environmental Psychology, 44, 149-159.

Birchall, J. and Simmons, R. 2004. What motivates members to participate in co-operative and mutual businesses? Annals of Public and Cooperative Economics, 75, 465-495.

Blunkett, D. 2003. Civil renewal: A new agenda. Home Office, London. Available at: www.homeoffice.gov.uk/docs2/civilrennewagenda.pdf.

Brady, H. E., Verba, S. and Schlozman, K. L. 1995. Beyond SES: A resource model of political participation. American Political Science Review, 89, 271-294.

Cambridge Dictionary. n.d. Acceptance [Online]. Cambridge Advanced Learner's Dictionary \& Thesaurus. Available at: https:/dictionary.cambridge.org/dictionary/english/ acceptance [Accessed 5 April 2018]. 
Charness, G. and Grosskopf, B. 2001. Relative payoffs and happiness: An experimental study. Journal of Economic Behavior \& Organization, 45, 301-328.

De Young, R. 2000. New ways to promote proenvironmental behavior: Expanding and evaluating motives for environmentally responsible behavior. Journal of Social Issues, 56, 509-526.

DECC. 2011. UK renewable energy roadmap. Department of Energy \& Climate Change, London Available at: www.gov.uk/.../2167-uk-renewable-energy-roadmap.pdf.

DECC. 2014. Community energy strategy. Department of Energy \& Climate Change, London. Available at: www.gov.uk/government/uploads/system/uploads/attachment data/file/275163/20140126Community_Energy_Strategy.pdf.

DECC. 2015. Community energy strategy update. Department of Energy \& Climate Change, London. Available at: www.gov.uk/government/uploads/system/uploads/ attachment_data/file/414446/CESU_FINAL.pdf.

DeMarco, J. P. 2001. Substantive equality: A basic value. Journal of Social Philosophy, 32, 197-206.

Department for Business, Energy \& Industrial Strategy. 2019. The UK's draft integrated National Energy and Climate Plan (NECP). Department for Business, Energy \& Industrial Strategy, London. Available at: https://ec.europa.eu/energy/sites/ener/files/ documents/unitedkingdom_draftnecp.pdf.

Devine-Wright, P. 2004. Towards zero-carbon: Citizenship, responsibility and the public acceptability of sustainable energy technologies. In: Buckle, C. (ed.) Proceedings of Conference C81 of the Solar Energy Society, UK Section of the International Solar Energy Society, 21 September 2004, London.

Devine-Wright, P. 2007. Energy citizenship: Psychological aspects of evolution in sustainable energy technologies. In: Murphy, J. (ed.) Governing technology for sustainability. London: Earthscan.

Diekmann, A. and Preisendörfer, P. 2003. Green and greenback: The behavioral effects of environmental attitudes in low-cost and high-cost situations. Rationality and Society, 15, 441-472.

Dinham, A. 2010. Active citizenship and the big society. Faiths \& Civil Society Unit, Goldsmiths, University of London. Available at: www.gold.ac.uk/media/documents-bysection/departments/research-centres-and-units/research-centres/centre-for-lifelong-learning/ Active-Citizenship-and-the-Big-Society.doc.

Dobson, A. 2003. Citizenship and the environment. Oxford: Oxford University Press.

DTI and DEFRA. 2003. Our energy future: Creating a low carbon economy. Department of Trade and Industry, London. Available at: www.dti.gov.uk/energy/whitepaper/ ourenergyfuture.pdf.

Faulks, K. 2000. Citizenship. New York: Routledge.

HM Government. 2009. The UK renewable energy strategy. The Stationery Office, London. Available at: www.official-documents.gov.uk/document/cm76/7686/7686.pdf.

Homans, G. 1974. Social behaviour: Its elementary forms (2nd edn.). New York: Harcourt Brace Jovanovich.

Illuzzi, M. J. 2014. Equality. In: Gibbons, M. T., Coole, D., Ellis, E. and Ferguson, K. (eds.) The encyclopedia of political thought. Chichester, UK: Wiley-Blackwell.

Kaplan, S. 2000. New ways to promote proenvironmental behavior: Human nature and environmentally responsible behavior. Journal of Social Issues, 56, 491-508.

Kollmuss, A. and Agyeman, J. 2002. Mind the gap: Why do people act environmentally and what are the barriers to pro-environmental behavior? Environmental Education Research, 8, 239-260. 
Lipp, J. and McMurtry, J. 2015. Benefits of renewable energy co-operatives: Summary of literature review from the Measuring the Co-operative Difference Research Network. Measuring the Co-operative Difference Research Network, Canada. Available at: http://hdl.handle.net/10587/1608.

Local Energy Scotland. 2015. Good practice principles for shared ownership of onshore renewable energy developments. Energy Saving Trust, Edinburgh. Available at: www.localenergyscotland.org/media/79714/Shared-Ownership-GoodPractice-Principles.pdf.

Lovins, A. B. 1977. Soft energy paths: Toward a durable peace. Cambridge, MA: Ballinger Publishing and Friends of the Earth International.

Lowndes, V., Pratchett, L. and Stoker, G. 2001. Trends in public participation: Part 2citizens' perspectives. Public Administration, 79, 445-455.

Lubell, M. 2002. Environmental activism as collective action. Environment and Behavior, 34, 431-454.

McLean, I. and McMillan, A. 2009. The concise Oxford dictionary of politics. Oxford: Oxford University Press.

Merkel, W. 2014. Is capitalism compatible with democracy? Zeitschrift für Vergleichende Politikwissenschaft, 8, 109-128.

O'Connell, M. 2004. Fairly satisfied: Economic equality, wealth and satisfaction. Journal of Economic Psychology, 25, 297-305.

Okun, A. M. 1975. Equality and efficiency: The big tradeoff. Washington, DC: The Brookings Institution.

Olson, M. 1965. The Logic of collective action: Public goods and the theory of groups (revised edn.). London: Harvard University Press.

Osbaldiston, R. and Schott, J. P. 2011. Environmental sustainability and behavioral science: Meta-analysis of proenvironmental behavior experiments. Environment and Behavior, 44, 257-299.

Patterson, W. 1999. Transforming electricity: The coming generation of change. Abingdon, UK: Earthscan.

Pattie, C., Seyd, P. and Whiteley, P. 2003. Citizenship and civic engagement: Attitudes and behaviour in Britain. Political Studies, 51, 443-468.

Pellegrini-Masini, G., Corvino, F. and Pirni, A. 2019. Climate justice in practice: Adapting democratic institutions for environmental citizenship. In: Harris, P. G. (ed.) A research agenda for climate justice. London: Edward Elgar Publishing.

Potter, J. 1996. Representing reality: Discourse, rhetoric and social construction. London: Sage.

Prior, D., Stewart, J. and Walsh, K. 1995. Citizenship: Rights, community and participation. London: Pitman.

Putnam, R. 1993. Making democracy work: Civic traditions in modern Italy. Princeton, NJ: Princeton University Press.

Reeve, A. 2009. Citizenship. In: McLean, I. and McMillan, A. (eds.) The concise Oxford dictionary of politics (3rd edn.). Oxford: Oxford University Press.

Rifkin, J. 2002. The hydrogen economy: The creation of the worldwide energy web and the redistribution of power on Earth. Cambridge: Polity Press.

Scottish Government. 2011. 2020 routemap for renewable energy in Scotland. APS Group Scotland, Edinburgh. Available at: www.gov.scot/Resource/Doc/917/0118802.pdf.

Simmons, R. and Birchall, J. 2003. Bringing citizens back into public services: Strengthening the "Participation Chain". ECPR Joint Sessions, Edinburgh, 28 March-2 April 2003. 


\section{Citizens and renewable energy}

Smith, M. J. 1998. Ecologism: Towards ecological citizenship. Buckingham, UK: Open University Press.

Sorokin, P. 1954. The ways and power of love. Boston, MA: Beacon Press.

Stern, P. C. 2000. New environmental theories: Toward a coherent theory of environmentally significant behavior. Journal of Social Issues, 56, 407-424.

Stern, P. C., Dietz, T. and Kalof, L. 1993. Value orientations, gender, and environmental concern. Environment and Behavior, 25, 322-348.

Stern, P. C., Dietz, T., Abel, T. D., Guagnano, G. A. and Kalof, L. 1999. A value-belief-norm theory of support for social movements: The case of environmentalism. Human Ecology Review, 6, 81-97.

Stürmer, S. and Kampmeier, C. 2003. Active citizenship: The role of community identification in community volunteerism and local participation. Psychologica Belgica, 43, $103-122$.

Szarka, J. 2007. Wind power in Europe: Politics, business and society, Basingstoke, UK: Palgrave Macmillan.

The CIC Project Team. 2004. Community interest companies: An introduction to community interest companies. Department of Trade and Industry, London. Available at: www.dti.gov.uk/cics/pdfs/cicfactsheet1.pdf.

Tyler, T. R., Rasinski, K. A. and Griffin, E. 1986. Alternative images of the citizen: Implications for public policy. American Psychologist, 41, 970-978.

Verba, S., Schlozman, K. L. and Brady, H. E. 1995. Voice and equality: Civic voluntarism in American politics. Cambridge, MA: Harvard University Press.

Whiteley, P. and Seyd, P. 1996. Rationality and party activism: Encompassing tests of alternative models of political participation. European Journal of Political Research, 29, 215-234.

Wilkinson, R. and Pickett, K. 2011. The spirit level: Why greater equality makes societies stronger. New York: Bloomsbury Press.

Wüstenhagen, R., Wolsink, M. And Bürer, M. J. 2007. Social acceptance of renewable energy innovation: An introduction to the concept. Energy Policy, 35, 2683-2691. 
benefits concerning a hypothetical behaviour, such as supporting or opposing a proposed wind farm or joining a wind farm co-operative.

The influence of costs and benefits on participatory behaviours and environmentally responsible behaviours (ERBs) is widely acknowledged (e.g. Whiteley and Seyd, 1996; Stern, 2000; Diekmann and Preisendörfer, 2003; Simmons and Birchall, 2003). Therefore, following Stern (2000), "perceived costs" and "perceived benefits" are considered as psychological variables in the theoretical framework outlined in this section. The adoption of the labels "perceived costs" and "perceived benefits" instead of "costs" and "incentives" underlines the assumption that what ultimately influences behavioural intentions are neither objective "costs" nor objective "benefits", but rather the subjective perception of these costs and benefits. To explain individuals' choices of whether to engage in ERBs, the significance of their perceived benefits and costs was indicated:

We argue that acting a pro-environmental behaviour is the result of an individual choice which follows a subjective cost-benefit analysis. This cost-benefit analysis is influenced primarily by the goal orientation of an individual at a certain point in time, which is in turn ultimately determined by the level of satisfaction of their needs. Secondarily by the availability of financial resources and the level of knowledge and information that an individual holds about the best course of action to achieve their main goal(s).

(Pellegrini-Masini, 2007, p. 3)

Therefore pro-environmental attitudes play a role, along with other value-based assessments regarding the cost and benefits of a considered behaviour, because acting pro-environmentally might produce the benefit of avoiding cognitive dissonance with one's pro-environmental attitudes (Thøgersen, 2004).

The pre-eminence of perceived costs and benefits in determining the acceptability of renewable energy installations has been more recently supported by a comprehensive literature review. This stresses the relevance of contextual factors, along with environmental attitudes, in determining the acceptance of energy alternatives, thereby suggesting that this approach might be a viable theoretical standpoint which could further the explanation of the acceptance of energy infrastructure (Perlaviciute and Steg, 2014).

\section{Notes}

1 The authors limit themselves to defining it as follows: "A concern that wind development would introduce general unwanted change to the community ..." (Jones and Eiser, 2009, p. 4611).

2 "To deliver on its targets WAG [Welsh Assembly Government] planning guidance identified seven Strategic Search Areas ... suitable for large-scale wind energy development, amounting to a significant concentration of development potential on specific, remote areas of rural Wales" (Munday et al., 2011, p. 2). 
3 The acronym NIMBY, i.e. "not in my back yard", is defined as "a colloquialism signifying one's opposition to the locating of something considered undesirable in one's neighborhood" (Kinder, 2016).

4 While there is no classification of wind farms based on size, the Scottish Government (2009) considers commercial farms to be of $20 \mathrm{MW}$ or more.

5 https://energy4all.co.uk/.

\section{References}

Agterbosch, S., Meertens, R. M. and Vermeulen, W. J. V. 2009. The relative importance of social and institutional conditions in the planning of wind power projects. Renewable and Sustainable Energy Reviews, 13, 393-405.

Aitken, M. 2010. Wind power and community benefits: Challenges and opportunities. Energy Policy, 38, 6066-6075.

Awerbuch, S. 2006. Portfolio-based electricity generation planning: Policy implications for renewables and energy security. Mitigation and Adaptation Strategies for Global Change, 11, 693-710.

Bamberg, S. and Möser, G. 2007. Twenty years after Hines, Hungerford, and Tomera: A new meta-analysis of psycho-social determinants of pro-environmental behaviour. Journal of Environmental Psychology, 27, 14-25.

Barr, S., Gilg, A. W. and Ford, N. 2005. The household energy gap: Examining the divide between habitual- and purchase-related conservation behaviours. Energy Policy, $33,1425-1444$.

Barry, J. and Proops, J. 1999. Seeking sustainability discourses with Q methodology. Ecological Economics, 28, 337-345.

Bauwens, T. 2015. Propriété coopérative et acceptabilité sociale de l'éolien terrestre. Reflets et perspectives de la vie économique, LIV, 59-70.

Bauwens, T. and Devine-Wright, P. 2018. Positive energies? An empirical study of community energy participation and attitudes to renewable energy. Energy Policy, 118, 612-625.

Bauwens, T., Gotchev, B. and Holstenkamp, L. 2016. What drives the development of community energy in Europe? The case of wind power cooperatives. Energy Research and Social Science, 13, 136-147.

Bellhouse, G. 2004. Low frequency noise and infrasound from wind turbine generators: A literature review. Available at: http://canwea.ca/pdf/talkwind/Low\%20Frequency\% 20 Noise $\% 20$ and $\% 20$ Infrasound $\% 20$ from $\% 20$ Wind $\% 20$ Turbine $\% 20$ Generators.pdf. [Accessed 19 December 2016].

Bishop, I. D. and Miller, D. R. 2007. Visual assessment of off-shore wind turbines: The influence of distance, contrast, movement and social variables. Renewable Energy, 32, 814-831.

Bonaiuto, M., Carrus, G., Martorella, H., Bonnes, M. and Mirilia, B. 2002. Local identity processes and environmental attitudes in land use changes: The case of natural protected areas. Journal of Economic Psychology, 23, 631-653.

Braunholtz, S. and McWhannel, F. 2003. Public attitudes to windfarms: A survey of local residents in Scotland. MORI Scotland, Edinburgh. Available at: www.scotland.gov.uk/ socialresearch.

Cass, N., Walker, G. and Devine-Wright, P. 2010. Good neighbours, public relations and bribes: The politics and perceptions of community benefit provision in renewable energy development in the UK. Journal of Environmental Policy \& Planning, 12, 255-275. 


\section{Wind energy acceptability}

Country Guardian. 2000. The case against wind farms [Online]. Available at: www. digknow.com/pdf/The\%20Case\%20Against\%20Windfarms.pdf [Accessed 28 March 2011].

CSE (Centre for Sustainable Energy). 2005. Community benefits from wind power: A study of UK practice \& comparison with leading European countries. Department of Trade and Industry, London. Available at: www.cse.org.uk/pdf/pub1049.pdf.

CSE (Centre for Sustainable Energy). 2009. Delivering community benefits from wind energy development: A toolkit. Department of Trade and Industry, London. Available at: www.cse.org.uk/downloads/toolkits/community-energy/planning/renewables/deliveringcommunity-benefits-from-wind-energy-tookit.pdf.

Dalton, G. J., Lockington, D. A. and Baldock, T. E. 2008. A survey of tourist attitudes to renewable energy supply in Australian hotel accommodation. Renewable Energy, 33, 2174-2185.

Department of Trade and Industry. 2004. Co-operative energy: Lessons from Denmark and Sweden. Department of Trade and Industry, London.

Department of Trade and Industry and Co-operatives UK. 2005. Co-operative energy: Lessons from Denmark and Sweden. Department of Trade and Industry, London. Available at: www.oti.globalwatchonline.com/online_pdfs/36247MR.pdf?pubpdfd load $=05 \% 2 \mathrm{~F} 592$.

Devine-Wright, P. 2005a. Beyond NIMBYism: Towards an integrated framework for understanding public perceptions of wind energy. Wind Energy, 8, 125-139.

Devine-Wright, P. 2005b. Local aspects of UK renewable energy development: Exploring public beliefs and policy implications. Local Environment, 10, 57-69.

Devine-Wright, P. 2008. Reconsidering public acceptance of renewable energy technologies: A critical review. In: Jamasb, T., Grubb, M. and Pollitt, M. (eds.) Delivering a low carbon electricity system: Technologies, economics and policy. Cambridge: Cambridge University Press.

Devine-Wright, P. 2009. Rethinking NIMBYism: The role of place attachment and place identity in explaining place-protective action. Journal of Community \& Applied Social Psychology, 19, 426-441.

Devine-Wright, P. 2013. Explaining "NIMBY" objections to a power line: The role of personal, place attachment and project-related factors. Environment and Behavior, 45, 761-781.

Devine-Wright, P. and Devine-Wright, H. 2006. Social representations of intermittency and the shaping of public support for wind energy in the UK. International Journal of Global Energy Issues, 25, 243-256.

Devine-Wright, P. and Howes, Y. 2010. Disruption to place attachment and the protection of restorative environments: A wind energy case study. Journal of Environmental Psychology, 30, 271-280.

Devine-Wright, P. and Wiersma, B. 2020. Understanding community acceptance of a potential offshore wind energy project in different locations: An island-based analysis of "place-technology fit". Energy Policy, 137, 111086. Available at https://doi. org/10.1016/j.enpol.2019.111086.

Diekmann, A. and Preisendörfer, P. 2003. Green and greenback. Rationality and Society, $15,441-472$.

Dimitropoulos, A. and Kontoleon, A. 2009. Assessing the determinants of local acceptability of wind-farm investment: A choice experiment in the Greek Aegean Islands. Energy Policy, 37, 1842-1854. 
Dudleston, A. 2000. Public attitudes towards wind farms in Scotland: Results of a residents survey. The Scottish Executive, Edinburgh.

Ellis, G., Barry, J. and Robinson, C. 2007. Many ways to say no, different ways to say yes: Applying Q-Methodology to understand public acceptance of wind farm proposals. Journal of Environmental Planning and Management, 50, 517-551.

Eltham, D. C., Harrison, G. P. and Allen, S. J. 2008. Change in public attitudes towards a Cornish wind farm: Implications for planning. Energy Policy, 36, 23-33.

Energy4All. 2009. Clean, green energy-Let's cooperate [Online].

Exeter Enterprises. 1994. Public attitudes towards wind power-A survey of opinion in Cornwall and Devon. Department of Trade and Industry, London.

Firestone, J. and Kempton, W. 2007. Public opinion about large offshore wind power: Underlying factors. Energy Policy, 35, 1584-1598.

Firestone, J., Kempton, W. and Krueger, A. 2009. Public acceptance of offshore wind power projects in the USA. Wind Energy, 12, 183-202.

Frantál, B. and Kunc, J. 2011. Wind turbines in tourism landscapes: Czech experience. Annals of Tourism Research, 38, 499-519.

Glasgow Caledonian University, Moffat Centre and Cogentsi. 2008. The economic impact of wind farms on Scottish Tourism: A report for the Scottish Government:: Energy and Climate Change Directorate, Scottish Government, Edinburgh. Available at: www.scotland.gov.uk/Resource/Doc/214910/0057316.pdf.

Gross, C. 2007. Community perspectives of wind energy in Australia: The application of a justice and community fairness framework to increase social acceptance. Energy Policy, 35, 2727-2736.

Haggett, C. 2004. Tilting at windmills? The attitude-behaviour gap in renewable energy conflicts. Landscape Research Group, University of Newcastle, UK. Available at: www.psi.org.uk/ehb/docs/finalreport-Haggett.pdf.

Hidalgo, M. C. and Hernández, B. 2001. Place attachment: Conceptual and empirical questions. Journal of Environmental Psychology, 21, 273-281.

Hoepman, N. 1998. Four de Wyn, Provinsje Friesland.

Janssen, S. A., Eisses, A. R., Vos, H. and Pedersen, E. 2009. Exposure-response relationships for annoyance by wind turbine noise: A comparison with other stationary sources. Eighth European Conference on Noise Control 2009 (EURONOISE 2009)Proceedings of the Institute of Acoustics, 26-28 October, Institute of Acoustics (Great Britain), Edinburgh.

Jones, C. R. and Eiser, J. R. 2009. Identifying predictors of attitudes towards local onshore wind development with reference to an English case study. Energy Policy, 37, 4604-4614.

Kinder, P. D. 2016. Not in my backyard phenomenon (NIMBY) [Online]. Encyclopcedia Britannica. Available at: www.britannica.com/topic/Not-in-My-Backyard-Phenomenon [Accessed 20 April 2011].

Klick, H. and Smith, E. R. A. N. 2010. Public understanding of and support for wind power in the United States. Renewable Energy, 35, 1585-1591.

Kollmuss, A. and Agyeman, J. 2002. Mind the gap: Why do people act environmentally and what are the barriers to pro-environmental behavior? Environmental Education Research, 8, 239-260.

Krohn, S. and Damborg, S. 1999. On public attitudes towards wind power. Renewable Energy, 16, 954-960.

Lipp, J. and McMurtry, J. 2015. Benefits of renewable energy co-operatives: Summary of literature review from the Measuring the Co-operative Difference Research Network. 
Measuring the Co-operative Difference Research Network. Available at: www. cooperativedifference.coop/wp-content/uploads/2015/02/Benefits-of-Renewable-EnergyCo-ops.pdf.

Lothian, A. 2008. Scenic perceptions of the visual effects of wind farms on South Australian landscapes. Geographical Research, 46, 196-207.

Maruyama, Y., Nishikido, M. and Iida, T. 2007. The rise of community wind power in Japan: Enhanced acceptance through social innovation. Energy Policy, 35, 2761-2769.

Maslow, A. H. 1987. Motivation and personality. New York: Harper \& Row.

McLaren Loring, J. 2007. Wind energy planning in England, Wales and Denmark: Factors influencing project success. Energy Policy, 35, 2648-2660.

Meyerhoff, J., Ohl, C. and Hartje, V. 2010. Landscape externalities from onshore wind power. Energy Policy, 38, 82-92.

MORI Scotland. 2002. Tourist attitudes towards wind farms. Research study conducted for Scottish Renewables Forum and the British Wind Energy Association, summary report, MORI Scotland, Edinburgh.

Munday, M., Bristow, G. and Cowell, R. 2011. Wind farms in rural areas: How far do community benefits from wind farms represent a local economic development opportunity? Journal of Rural Studies, 27(1), 1-12.

Oishi, S., Diener, E. F., Lucas, R. E., Suh, E. M., Diener, E. F., Lucas, R. E. and Suh, E. M. 1999. Cross-cultural variations in predictors of life satisfaction: Perspectives from needs and values. Personality and Social Psychology Bulletin, 25, 980-990.

Olesen, G. 1998. Large scale implementation of renewable and sustainable energy. Danish Organisation for Renewable Energy, Arhus, Denmark.

Olson, M. 1965. Logic of collective action public goods and the theory of groups (revised edn.). London: Harvard University Press.

Owen, G. and Hunt, P. 2004. Community engagement in energy through energy mutuals. London: Mutuo.

Pedersen, E. and Larsman, P. 2008. The impact of visual factors on noise annoyance among people living in the vicinity of wind turbines. Journal of Environmental Psychology, 28, 379-389.

Pedersen, E. and Persson-Waye, K. 2004. Perception and annoyance due to wind turbine noise: A dose-response relationship. Journal of the Acoustical Society of America, 116, 3460-3470.

Pedersen, E. and Persson-Waye, K. 2007. Wind turbine noise, annoyance and selfreported health and well-being in different living environments. Occupational and Environmental Medicine, 64, 480-486.

Pedersen, E. and Persson-Waye, K. 2008. Wind turbines-low level noise sources interfering with restoration? Environmental Research Letters, 3, 015002.

Pedersen, E., Hallberg, L.-M. and Waye, K. P. 2007. Living in the vicinity of wind turbines: A grounded theory study. Qualitative Research in Psychology, 4, 49-63.

Pellegrini-Masini, G. 2007. The carbon-saving behaviour of residential households. Futures of Cities-51st IFHP World Congress, 23-26 September 2007, Copenhagen.

Perlaviciute, G. and Steg, L. 2014. Contextual and psychological factors shaping evaluations and acceptability of energy alternatives: Integrated review and research agenda. Renewable and Sustainable Energy Reviews, 35, 361-381.

Roberts, M. and Roberts, J. 2009. Evaluation of the scientific literature on the health effects associated with wind turbines and low frequency sound. Exponent, Wood Dale, IL.

Scottish Government. 2009. Community renewable energy toolkit. Scottish Government, Edinburgh. 
Scottish Government. 2013. Good practice principles for community benefits from onshore renewable energy developments. Energy and Climate Change Directorate, Scottish Government, Edinburgh. Available at: www2.gov.scot/resource/0043/0043 8782.pdf.

Scottish Government. 2015. Good practice principles for shared ownership of onshore renewable energy developments. Energy Saving Trust, Edinburgh. Available at: www. localenergyscotland.org/media/79714/Shared-Ownership-Good-Practice-Principles.pdf.

SEI. 2003. Attitudes towards the development of wind farms in Ireland. Renewable Energy Information Office, Bandon. Ireland. Available at: www.seai.ie/uploadedfiles/ RenewableEnergy/Attitudestowardswind.pdf.

Sheldon, K. M., Elliot, A. J., Kim, Y. and Kasser, T. 2001. What is satisfying about satisfying events? Testing 10 candidate psychological needs. Journal of Personality and Social Psychology, 80(2), 325-339.

Shen, J. and Saijo, T. 2008. Reexamining the relations between socio-demographic characteristics and individual environmental concern: Evidence from Shanghai data. Journal of Environmental Psychology, 28, 42-50.

Simmons, R. and Birchall, J. 2003. Bringing citizens back into public services: Strengthening the "Participation Chain". ECPR Joint Sessions, Edinburgh, 28 March-2 April 2003.

Sims, S. and Dent, P. 2007. Property stigma: Wind farms are just the latest fashion. Journal of Property Investment \& Finance, 25, 626-651.

Sims, S., Dent, P. and Oskrochi, G. 2008. Modelling the impact of wind farms on house prices in the UK. International Journal of Strategic Property Management, 12, 251-269.

Spence, A., Venables, D., Pidgeon, N., Poortinga, W. and Demski, C. 2010. Public perceptions of climate change and energy futures in Britain: Summary findings of a survey conducted from January to March 2010. Understanding Risk Working Paper 10-01, School of Psychology, Cardiff University. Available at: https://sp.ukdataservice.ac.uk/ doc/6581/mrdoc/pdf/6581final_report.pdf.

Sperling, K., Hvelplund, F. and Mathiesen, B. V. 2010. Evaluation of wind power planning in Denmark: Towards an integrated perspective. Energy, 35, 5443-5454.

Stern, P. C. 2000. New environmental theories: Toward a coherent theory of environmentally significant behavior. Journal of Social Issues, 56, 407-424.

Stern, P. C., Dietz, T., Abel, T. D., Guagnano, G. A. and Kalof, L. 1999. A value-belief-norm theory of support for social movements: The case of environmentalism. Human Ecology Review, 6, 81-97.

Sterzinger, G., Beck, F. and Kostiuk, D. 2003. The effect of wind development on local property values. Washington: Renewable Energy Policy Project.

Sustainable Development Commission. 2005. Wind power in the UK: A guide to the key issues surrounding onshore wind power development in the UK. Sustainable Development Commission, London. Available at: www.sd-commission.org.uk/data/files/ publications/Wind_Energy-NovRev2005.pdf.

Swofford, J. and Slattery, M. 2010. Public attitudes of wind energy in Texas: Local communities in close proximity to wind farms and their effect on decision-making. Energy Policy, 38, 2508-2519.

Taormina, R. J. and Gao, J. H. 2013. Maslow and the motivation hierarchy: Measuring satisfaction of the needs. American Journal of Psychology, 126, 155-177.

The Isle of Gigha Heritage Trust. n.d. Frequently asked questions about the Gigha Windmills [Online]. Available at: www.gigha.org.uk/windmills/TheStoryoftheWindmills.php [Accessed 2 March 2011]. 
Thøgersen, J. 2004. A cognitive dissonance interpretation of consistencies and inconsistencies in environmentally responsible behavior. Journal of Environmental Psychology, 24, 93-103.

Toke, D. 2002. Wind power in UK and Denmark: Can rational choice help explain different outcomes? Environmental Politics, 11, 83-100.

Toke, D. 2005a. Community wind power in Europe and in the UK. Wind Engineering, 29, 301-308.

Toke, D. 2005b. Explaining wind power planning outcomes: Some findings from a study in England and Wales. Energy Policy, 33, 1527-1539.

Toke, D., Breukers, S. and Wolsink, M. 2008. Wind power deployment outcomes: How can we account for the differences? Renewable and Sustainable Energy Reviews, 12, $1129-1147$.

van Der Horst, D. 2007. NIMBY or not? Exploring the relevance of location and the politics of voiced opinions in renewable energy siting controversies. Energy Policy, 35 , 2705-2714.

van Der Horst, D. and Toke, D. 2010. Exploring the landscape of wind farm developments: Local area characteristics and planning process outcomes in rural England. Land Use Policy, 27, 214-221.

Vorkinn, M. and Riese, H. 2001. Environmental concern in a local context. Environment and Behavior, 33, 249-263.

Warren, C. R. and McFadyen, M. 2010. Does community ownership affect public attitudes to wind energy? A case study from south-west Scotland. Land Use Policy, 27, 204-213.

Warren, C., Lumsden, C., O’Dowd, S. and Birnie, R. 2005. "Green on green”: Public perceptions of wind power in Scotland and Ireland. Journal of Environmental Planning and Management, 48, 853-875.

Whiteley, P. and Seyd, P. 1996. Rationality and party activism: Encompassing tests of alternative models of political participation. European Journal of Political Research, 29, 215-234.

Williams, A. 1993. Role of fossil fuels in electricity generation and their environmental impact. Science, Measurement and Technology, 140, 8-12.

Wind Europe. 2019. Wind energy in Europe in 2018. Trends and statistics. Available at: https://windeurope.org/wp-content/uploads/files/about-wind/statistics/WindEuropeAnnual-Statistics-2018.pdf [Accessed 11 March 2020].

Wolsink, M. 2000. Wind power and the NIMBY-myth: Institutional capacity and the limited significance of public support. Renewable Energy, 21, 49-64.

Wolsink, M. 2007a. Planning of renewables schemes: Deliberative and fair decisionmaking on landscape issues instead of reproachful accusations of non-cooperation. Energy Policy, 35, 2692-2704.

Wolsink, M. 2007b. Wind power implementation: The nature of public attitudes: Equity and fairness instead of "backyard motives". Renewable and Sustainable Energy Reviews, 11, 1188-1207.

Young, B. 1993. Attitudes towards wind power: A Survey of opinion in Cornwall and Devon. Energy Technology Support Unit, Harwell, UK. 
and $6-10 \mathrm{~km}$ from the wind farm sites. ${ }^{8}$ Overall, a total of 1000 households were selected. Following recommended research practice (Edwards et al., 2002), several steps were adopted in order to increase the response rate. The selected households received a first letter along with a questionnaire and a prepaid stamped envelope. The letter introduced the research purpose and stressed the national importance of public opinion to the energy policy debate. After a week, a reminder letter was sent, and after another week, a third and final letter with another copy of the questionnaire and an additional prepaid stamped envelope was mailed.

The questionnaire was kept as short as possible in order to achieve a better response rate, in keeping with Edwards et al.'s (2002) determination that questionnaire length was the fourth most important characteristic in determining response rate. The questionnaire was limited to three pages, printed on both sides, and used Arial font size 10 for readability's sake, as suggested by Bradburn et al. (2004b).

Data from returned questionnaires was entered in SPSS (Statistical Package for the Social Sciences). Data quality was later checked by randomly selecting 50 questionnaires in order to cover the entire questionnaire set uniformly. When a mistake was identified in the questionnaire's entered variables, adjacent questionnaires (cases in SPSS) were also checked. Each questionnaire had 51 variables; over 2500 variables were checked and only 6 mistakes were found, i.e. the error rate was 0.24 per cent.

The questionnaire had a 31.5 per cent response rate: 315 questionnaires returned of 1000 mailed. The response rate in itself was an improvement over the pilot questionnaire's 17.5 per cent response rate and compares favourably with other postal survey research on onshore wind farms, many of which had lower response rates - e.g. only 13.3 per cent in the case of Swofford and Slattery, (2010).

\section{Notes}

1 Available at: https://energy4all.co.uk.

2 Available at: http://simd.scotland.gov.uk/map.

3 The percentage of "population income deprived" was calculated using data for the following categories of citizens:

- number of adults (aged 16-59) receiving Income Support (Department for Work and Pensions [DWP], April 2005)

- number of adults (aged 60 plus) receiving Guaranteed Pension Credit (DWP, May 2005)

- number of children (aged 0-15) dependent on a recipient of Income Support (DWP, April 2005)

- number of adults receiving (all) Job Seekers Allowance (DWP, April 2005)

- number of children (aged 0-15) dependent on a recipient of Job Seekers Allowance (all) (DWP, April 2005)

- number of adults and children in Tax Credit families on low incomes (Her Majesty's Revenue \& Customs [HMRC], August 2006).

For further details see: Office of the Chief Statistician (2009). 
4 Data available from: www.sns.gov.uk/default.aspx [Accessed 19 October 2010].

5 From www.sns.gov.uk/ [Accessed 25 October 2010]:

The Scottish Index of Multiple Deprivation (SIMD) provides a relative ranking of the data zones in Scotland from 1 (most deprived) to 6505 (least deprived) based on a weighted combination of data in the domains of Current Income, Housing, Health, Education, Skills and Training, Employment and Geographic Access and Crime (SIMD 2006 onwards).

6 Data available at: www.sns.gov.uk/default.aspx [Accessed 19 October 2010].

7 The Scottish Government Urban Rural Classification provides a standard definition of rural areas in Scotland. It distinguishes between urban, rural and remote areas, based on a core definition of rurality which defines settlements of 3000 or fewer people as rural, and aims to assist understanding of the issues facing these areas. The Scottish Government has used the classification to improve the rural evidence base. It distinguishes between the following six categories: (1) large urban areas; (2) other urban areas; (3) accessible small towns; (4) remote small towns; (5) accessible rural areas; and (6) remote rural areas. For further information see the Scottish Government website: www2.gov.scot/urbanrural.

8 Addresses were identified using the Royal Mail's Postal Address file.

\section{References}

Bamberg, S. and Möser, G. 2007. Twenty years after Hines, Hungerford, and Tomera: A new meta-analysis of psycho-social determinants of pro-environmental behaviour. Journal of Environmental Psychology, 27, 14-25.

Bartlett, J. E., Kotrlik, J. W. and Higgins, C. C. 2001. Organizational research: Determining appropriate sample size in survey research. Information Technology, Learning, and Performance Journal, 19, 43-50.

Bauwens, T. and Devine-Wright, P. 2018. Positive energies? An empirical study of community energy participation and attitudes to renewable energy. Energy Policy, 118, 612-625.

Bishop, I. D. and Miller, D. R. 2007. Visual assessment of off-shore wind turbines: The influence of distance, contrast, movement and social variables. Renewable Energy, 32, 814-831.

Bradburn, N. M., Sudman, S. and Wansink, B. 2004a. Asking questions. San Francisco, CA: Jossey-Bass.

Bradburn, N. M., Sudman, S. and Wansink, B. 2004b. Asking questions: The definitive guide to questionnaire design (revised edn.). San Francisco, CA: Jossey-Bass.

Braunholtz, S. and McWhannel, F. 2003a. Public attitudes to windfarms. A survey of local residents in Scotland. Scottish Executive, Edinburgh. Available at: www. scotland.gov.uk/socialresearch.

Braunholtz, S. and McWhannel, F. 2003b. Public attitudes to windfarms: A survey of local residents in Scotland. MORI Scotland, Edinburgh. Available at: www.scotland. gov.uk/socialresearch.

Bryman, A. 2004. Social research methods. Oxford: Oxford University Press.

Cochran, W. G. 1977. Sampling techniques. New York: John Wiley \& Sons.

Corbetta, P. 1999. Metodologia e tecniche della ricerca sociale. Bologna: il Mulino. 
Corbetta, P. 2003. Social research: Theory, methods and techniques. London: Sage Publications.

Denzin, N. K. 1978. The research act (2nd edn.). New York: McGraw-Hill.

Diekmann, A. and Preisendörfer, P. 2003. Green and greenback: The behavioral effects of environmental attitudes in low-cost and high-cost situations. Rationality and Society, 15, 441-472.

Dobson, A. 2003. Citizenship and the environment. Oxford: Oxford University Press.

DTI. 2004. Co-operative energy: Lessons from Denmark and Sweden. Department of Trade and Industry, London.

Edwards, P., Roberts, I., Clarke, M., Diguiseppi, C., Pratap, S., Wentz, R. and Kwan, I. 2002. Increasing response rates to postal questionnaires: Systematic review. The BMJ, $324,1183$.

Falck Renewables. 2008. Cushnie wind farm non-technical summary. Available at: www. cushniewindenergy.co.uk/Userfiles/File\%5CCushnie\%20NTS\%20PDF.pdf.

Falck Renewables. 2010. Nigg wind farm non-technical summary. Available at: www. niggwindenergy.co.uk/Userfiles/File\%5CApplication\%20Documents\%5C2010\%20 SEI\%5C2010\%20Non\%20technical\%20summary\%5CNon-Technical\%20Summary_ Low\%20Res_v1.pdf.

Gillham, B. 2000. Developing a questionnaire. London: Continuum.

Groothuis, P. A., Groothuis, J. D. and Whitehead, J. C. 2008. Green vs. green: Measuring the compensation required to site electrical generation windmills in a viewshed. Energy Policy, 36, 1545-1550.

Henwood, K. and Pidgeon, N. 1994. Beyond the qualitative paradigm: A framework for introducing diversity within qualitative psychology. Journal of Community \& Applied Social Psychology, 4, 225-238.

Hirst, P. 1994. Associative democracy: New forms of economic and social governance. Cambridge: Polity Press.

Hirst, P. 2002. Renewing democracy through associations. The Political Quarterly, 73, 409-421.

Inglehart, R. 1977. The silent revolution: Changing values and political styles among Western publics. Princeton, NJ: Princeton University Press.

Jick, T. D. 1979. Mixing qualitative and quantitative methods: Triangulation in action. Administrative Science Quarterly, 24, 602-611.

Klick, H. and Smith, E. R. A. N. 2010. Public understanding of and support for wind power in the United States. Renewable Energy, 35, 1585-1591.

Maslow, A. H. 1987. Motivation and personality. New York: Harper \& Row.

Office of the Chief Statistician. 2009. Summary of methodological changes to the Scottish Index of Multiple Deprivation (SIMD). Office of the Chief Statistician, Edinburgh. Available at: www.scotland.gov.uk/Resource/Doc/933/0097285.doc.

Oishi, S., Diener, E. F., Lucas, R. E. and Suh, E. M. 1999. Cross-cultural variations in predictors of life satisfaction: Perspectives from needs and values. Personality and Social Psychology Bulletin, 25, 980-990.

ONS. 2018. Regional statistics 2003-2017: Installed capacity. Office for National Statistics, London. Available at: https://assets.publishing.service.gov.uk/government/uploads/system/ uploads/attachment_data/file/743827/Installed_capacity_of_sites_generating_electricity from_renewable_sources_2003-2017.xls?_ga $=2.131848271 .1175064298 .1566562378-$ 907690731.1566562378.

Oppenheim, A. N. 1998. Questionnaire design, interviewing and attitude measurement. London: Continuum. 
Popper, K. R. 1990. The logic of scientific discovery. Crows Nest, New South Wales, Australia: Unwin Hyman.

Rifkin, J. 2002. The hydrogen economy: The creation of the worldwide energy web and the redistribution of power on earth. Cambridge: Polity Press.

Robson, C. 2002. Real world research. Oxford: Blackwell Publishers.

Scottish Government. 2010. Scottish Planning Policy. The Scottish Government. Available at: www.scotland.gov.uk/Resource/Doc/300760/0093908.pdf [Accessed 10 March 2010].

Sheldon, K. M., Elliot, A. J., Kim, Y. and Kasser, T. 2001. What is satisfying about satisfying events? Testing ten candidates psychological needs. Journal of Personality and Social Psychology, 80, 325-339.

Shen, J. and Saijo, T. 2008. Reexamining the relations between socio-demographic characteristics and individual environmental concern: Evidence from Shanghai data. Journal of Environmental Psychology, 28, 42-50.

Swofford, J. and Slattery, M. 2010. Public attitudes of wind energy in Texas: Local communities in close proximity to wind farms and their effect on decision-making. Energy Policy, 38, 2508-2519.

TLT Solicitors. 2007. Bankable models which enable local community wind farm ownership: A report for the Renewables Advisory Board and DTI. Department of Trade and Industry, London. Available at: http://webarchive.nationalarchives.gov.uk/+/www. berr.gov.uk/files/file38707.pdf.

Toke, D. 2002. Wind power in UK and Denmark: Can rational choice help explain different outcomes? Environmental Politics, 11, 83-100.

TV Energy. 2004. TV Energy case study: Westmill Wind Farm, Oxfordshire. Available at: www.tvenergy.org/pdfs/westmil-web-case-study.pdf.

Wahba, M. A. and Bridwell, L. G. 1976. Maslow reconsidered: A review of research on the need hierarchy theory. Organizational behavior and human performance, 15 , 212-240.

Walker, G. 2007. Community energy initiatives: Embedding sustainable technology at a local level. Full research report. ESRC End of Award Report, RES-338-25-0010-A. Economic and Social Research Council, Swindon, UK.

Wallace, D. 1954. A case for-and against—mail questionnaires. Public Opinion Quarterly $18,40-52$.

Warren, C. R. and McFadyen, M. 2010. Does community ownership affect public attitudes to wind energy? A case study from south-west Scotland. Land Use Policy, 27, 204-213.

Warren, C., Lumsden, C., O’Dowd, S. and Birnie, R. 2005. "Green on Green": Public perceptions of wind power in Scotland and Ireland. Journal of Environmental Planning and Management, 48, 853-875.

West Coast Energy. 2005. Dunbeath Wind Farm environmental statement: Volume 4: Non-technical summary. West Coast Energy, Maes Gwern Mold, Wales. Available at: www.falckrenewables.com/ /media/Files/F/Falck-Renewables-Bm2012/pdfs/our-business/ elenco/Non $\% 20$ technical $\% 20$ summary\%20for $\% 20$ the $\% 20$ project.pdf.

Westmill Co-operative. 2005. Westmill Wind Farm co-operative share prospectus.

Westmill Co-operative. 2006a. 09/05/2006 Westmill board announcement. Available at: www.westmill.coop/westmill_newsdetails.asp?newsID=14.

Westmill Co-operative. 2006b. Westmill Wind Farm co-op blown away by share success. Available at: www.westmill.coop/westmill_newsdetails.asp?newsID=15 [Accessed 1 March 2006].

Wilson, N. and McClean, S. I. 1994. Questionnaire design: A practical introduction. University of Ulster. 
Woods, M. 2005. Contesting rurality: Politics in the British countryside. Aldershot, UK: Ashgate.

Yin, R. K. 1981. The case study crisis: Some answers. Administrative Science Quarterly, 26, 58-65.

Yin, R. K. 2003. Case study research. Thousand Oaks: CA: Sage Publications. 
respondents (one activist opponent and two councillors who opposed the wind farm) exhibited scepticism about this kind of enterprise, which they viewed as less efficient than traditional organisations. Other interviewees expressed positive opinions towards co-operatives, and stressed the democratic and more socially just character of these enterprises. This issue was not perceived as central in the debate about the local wind farm; nevertheless, opponents suggested that the co-operative scheme was a sort of propagandistic move, or even a way to disguise the promoter's subjective interests.

Finally, the interview transcripts offered further evidence against the continued usage of the NIMBY label as argued by Wolsink (2007). In fact, the egoistic motives assumed by the term NIMBY contrast with the sense of fairness displayed in wind farm opponents' answers: they rejected the possibility of installing the turbines elsewhere. This typology of opponents, which is not captured in Wolsink's (2007) classification, represented the vast majority of opponents' answers that I collected. Hence, despite its consistency with previous research (Wolsink, 2007), this analysis supports a further type of opposition, whose motivation appears to be a sense of fairness that emerges not only as a desire not to be discriminated against, but also to reject "damaging" wind farms elsewhere that might be equally close to local communities.

In conclusion, the analysis supported the framework proposed in Chapter 2, which integrates rational choice and socio-psychological theories. This appears to be a potentially useful theoretical approach for deepening our understanding of opposition to wind farms; it probes the interaction between attitudes, perceived costs and benefits and their relation to individuals' personal resources, while confirming the relevance of several issues identified in previous research on wind farms.

\section{Notes}

1 Midcounties Co-operative is the UK's largest independent co-operative, with over 700,000 members. It operates a range of businesses in food, travel, healthcare, funerals, childcare, energy, post offices, flexible benefits and telecoms. It generated a revenue of $£ 1.18$ billion in the financial year 2018-2019. See www.midcounties.coop/ siteassets/reports/18_19_Annual_Report.

2 The Westmill Wind Farm weblog has since been removed from the internet, hence it is not possible to reference it. The blog was copied in 2006 and used as material for the qualitative analysis, along with the interview transcripts.

\section{References}

Bailey, I. and Darkal, H. 2018. (Not) talking about justice: Justice self-recognition and the integration of energy and environmental-social justice into renewable energy siting. Local Environment, 23, 335-351.

Bonaiuto, M., Carrus, G., Martorella, H., Bonnes, M. and Mirilia, B. 2002. Local identity processes and environmental attitudes in land use changes: The case of natural protected areas. Journal of Economic Psychology, 23, 631-653. 
Botetzagias, I., Malesios, C., Kolokotroni, A. and Moysiadis, Y. 2015. The role of NIMBY in opposing the siting of wind farms: Evidence from Greece. Journal of Environmental Planning and Management, 58, 229-251.

Corraliza, J. A. and Berenguer, J. 2000. Environmental values, beliefs, and actions: A situational approach. Environment and Behavior, 32, 832-848.

de Groot, J. I. M. and Steg, L. 2009. Mean or green: Which values can promote stable pro-environmental behavior? Conservation Letters, 2, 61-66.

Devine-Wright, P. 2005. Beyond NIMBYism: Towards an integrated framework for understanding public perceptions of wind energy. Wind Energy, 8, 125-139.

Devine-Wright, P. 2009. Rethinking NIMBYism: The role of place attachment and place identity in explaining place-protective action. Journal of Community \& Applied Social Psychology, 19, 426-441.

Devine-Wright, P. and Howes, Y. 2010. Disruption to place attachment and the protection of restorative environments: A wind energy case study. Journal of Environmental Psychology, 30, 271-280.

Devine-Wright, P. and Wiersma, B. 2020. Understanding community acceptance of a potential offshore wind energy project in different locations: An island-based analysis of "place-technology fit". Energy Policy, 137, 111086. Available at https://doi. org/10.1016/j.enpol.2019.111086.

Diekmann, A. and Franzen, A. 1999. The wealth of nations and environmental concern. Environment and behavior, 31, 540-549.

Diekmann, A. and Preisendörfer, P. 2003. Green and greenback: The behavioral effects of environmental attitudes in low-cost and high-cost situations. Rationality and Society, 15, 441-472.

Dobson, A. 2003. Citizenship and the environment. Oxford: Oxford University Press.

DPDS Consulting Group. 2002. Environmental impact assessment: Non-technical summary. Available at: www.tvenergy.org/pdfs/Main\%20Text.pdf.

Gardner, G. T. and Stern, P. C. 2002. Environmental problems and human behaviour. Boston, MA: Pearson Custom Publishing.

Gross, C. 2007. Community perspectives of wind energy in Australia: The application of a justice and community fairness framework to increase social acceptance. Energy Policy, 35, 2727-2736.

Halliday, J. 1993. Wind energy: An option for the UK? IEE Proceedings A (Science, Measurement and Technology), 140(1), 53-62.

Inglehart, R. 1977. The silent revolution: Changing values and political styles among Western publics. Princeton, NJ: Princeton University Press.

Kyle, G. T., Mowen, A. J. and Tarrant, M. 2004. Linking place preferences with place meaning: An examination of the relationship between place motivation and place attachment. Journal of Environmental Psychology, 24, 439-454.

Lothian, A. 2008. Scenic perceptions of the visual effects of wind farms on south Australian landscapes. Geographical Research, 46, 196-207.

Maslow, A. H. 1987. Motivation and personality. New York: Harper \& Row.

McLean, I. and McMillan, A. 2009. The concise Oxford dictionary of politics. Oxford: Oxford University Press.

Molnarova, K., Sklenicka, P., Stiborek, J., Svobodova, K., Salek, M. and Brabec, E. 2012. Visual preferences for wind turbines: Location, numbers and respondent characteristics. Applied Energy, 92, 269-278.

ONS. 2001. Census 2001. Office for National Statistics, London. Available at: www. statistics.gov.uk/census. 
Perlaviciute, G. and Steg, L. 2014. Contextual and psychological factors shaping evaluations and acceptability of energy alternatives: Integrated review and research agenda. Renewable and Sustainable Energy Reviews, 35, 361-381.

Reeve, A. 2009. Citizenship. In McLean. I. and McMillan, A. (eds.) The concise Oxford dictionary of politics (3rd edn.). Oxford: Oxford University Press.

Rippetoe, P. A. and Rogers, R. W. 1987. Effects of components of protection-motivation theory on adaptive and maladaptive coping with a health threat. Journal of Personality and Social Psychology, 52(3), 596-604.

Steg, L., Bolderdijk, J. W., Keizer, K. and Perlaviciute, G. 2014. An integrated framework for encouraging pro-environmental behaviour: The role of values, situational factors and goals. Journal of Environmental Psychology, 38, 104-115.

Stern, P. C. 2000. New environmental theories: Toward a coherent theory of environmentally significant behavior. Journal of Social Issues, 56, 407-424.

Stern, P. C., Dietz, T., Abel, T. D., Guagnano, G. A. and Kalof, L. 1999. A value-belief-norm theory of support for social movements: The case of environmentalism. Human Ecology Review, 6, 81-97.

Sterzinger, G., Beck, F. and Kostiuk, D. 2003. The effect of wind development on local property values. Washington: Renewable Energy Policy Project.

Toke, D. 2002. Wind power in UK and Denmark: Can rational choice help explain different outcomes? Environmental Politics, 11, 83-100.

TV Energy. 2004. TV Energy case study: Westmill Wind Farm, Oxfordshire. Available at: www.tvenergy.org/pdfs/westmil-web-case-study.pdf.

van Veelen, B. and Haggett, C. 2016. Uncommon ground: The role of different place attachments in explaining community renewable energy projects. Sociologia Ruralis, 57, 533-554.

Verba, S., Schlozman, K. L. and Brady, H. E. 1995. Voice and equality: Civic voluntarism in American politics. Cambridge, MA: Harvard University Press.

Warren, C., Lumsden, C., O’Dowd, S. and Birnie, R. 2005. "Green on green”: Public perceptions of wind power in Scotland and Ireland. Journal of Environmental Planning and Management, 48, 853-875.

Weston, J. 2002. Public opinion on the impact of the proposed Westmill Farm wind farm Watchfield Oxfordshire. Impact Assessment Unit, School of Planning, Oxford Brookes University, UK.

Wolsink, M. 2000. Wind power and the NIMBY-myth: Institutional capacity and the limited significance of public support. Renewable Energy, 21, 49-64.

Wolsink, M. 2006. Invalid theory impedes our understanding: A critique on the persistence of the language of NIMBY. Transactions of the Institute of British Geographers, 31, 85-91.

Wolsink, M. 2007. Wind power implementation: The nature of public attitudes: Equity and fairness instead of "backyard motives". Renewable and Sustainable Energy Reviews, 11, 1188-1207.

$\mathrm{Xu}, \mathrm{Z}$. and Zhang, J. 2016. Antecedents and consequences of place attachment: A comparison of Chinese and Western urban tourists in Hangzhou, China. Journal of Destination Marketing \& Management, 5, 86-96. 


\section{Final remarks}

This chapter has presented the results of the postal survey of residents living within the vicinity of four proposed wind farm sites in Scotland and discussed their relative significance, as evaluated by appropriate statistical tests. The extent to which the results obtained support the theoretical framework developed in Chapter 2 is discussed in the next chapter.

\section{Notes}

1 The test initially came with a warning about its validity due to reaching the maximum number of iterations; it was therefore rerun with an increased number of iterations in the SPSS options tab. I couldn't find any advice against this, not even in the SPSS online guidelines, which simply recommend using a number of iterations of non-negative integer (IBM Knowledge Center, 2012). Marôco's (2007) simple advice is to increase the numbers of step-halving when a similar warning is shown about the maximum number of step-halving being reached.

2 Even in this case, as in the previous ordinal regression analysis, the first execution of this statistic returned a warning about its validity due to reaching the maximum number of step-halving. So this number was increased in the option tab of the SPSS ordinal regression test, as suggested by Marôco (2007).

\section{References}

Bryman, A. and Cramer, D. 2009. Quantitative data analysis with SPSS 14, 15 \& 16: A guide for social scientists. London: Routledge.

Cohen, L. and Holliday, M. 1982. Statistics for social scientists, London: Harper \& Row.

Diekmann, A. and Preisendörfer, P. 2003. Green and greenback: The behavioral effects of environmental attitudes in low-cost and high-cost situations. Rationality and Society, 15, 441-472.

Field, A. 2009. Discovering statistics using SPSS. London: Sage.

IBM Knowledge Center. 2012. Ordinal regression options [Online]. Available at: www.ibm.com/support/knowledgecenter/SSLVMB_21.0.0/com.ibm.spss.statistics. help/idh_plum_opt.htm [Accessed 10 March 2016].

Jones, C. R. and Eiser, J. R. 2009. Identifying predictors of attitudes towards local onshore wind development with reference to an English case study. Energy Policy, 37, 4604-4614.

Lipp, J. and McMurtry, J. J. 2015. Benefits of renewable energy co-operatives: Summary of literature review from the Measuring the Co-operative Difference Research Network. Measuring the Co-operative Difference Research Network, Canada. Available at: http://ec.msvu.ca:8080/xmlui/handle/10587/1608.

Marôco, J. 2007. Regressão ordinal. Análise estatística com o SPSS Statistics (3rd edn.). Lisbon: Edições Sílabo.

Nelsen, R. B. 2011. Kendall tau metric [Online]. Encyclopedia of mathematics. Available at: www.encyclopediaofmath.org/index.php?title=Kendall_tau_metric\&oldid=12869 [Accessed 13 November 2014].

Norušis, M. 2011. Ordinal regression. IBM SPSS statistics 19 advanced statistical procedures companion. Boston, MA: Addison-Wesley. 
198 Survey of four Scottish proposed wind farms

ONS. 2001. Census 2001. Available at: www.statistics.gov.uk/census [Accessed 21 November 2006].

ReStore. 2011a. Module 4: Multiple logistic regression. National Centre for Research Methods, Southampton, UK. Available at: www.restore.ac.uk/srme/www/fac/soc/wie/ research-new/srme/modules/mod4/module_4_-_logistic_regression.pdf [Accessed 20 February 2016].

ReStore. 2011b. Module 5: Ordinal regression. National Centre for Research Methods, Southampton, UK. Available at: www.restore.ac.uk/srme/www/fac/soc/wie/research-new/ srme/modules/mod5/module_5___ordinal_regression.pdf [Accessed 21 February 2016].

The Electoral Commission. 2005. Social exclusion and political engagement: Research report, November 2005. The Electoral Commission, London. Available at: www. electoralcommission.org.uk/sites/default/files/pdf_file/Social-exclusion-and-politicalengagement.pdf.

van der Horst, D. and Toke, D. 2010. Exploring the landscape of wind farm developments: Local area characteristics and planning process outcomes in rural England. Land Use Policy, 27, 214-221. 
opposition by ensuring that the perceived costs of wind deployment are minimised, while its perceived potential benefits are maximised.

In this regard, in 2014, the then UK Department of Energy and Climate Change (DECC) outlined a "community energy strategy" (DECC, 2014), which attempted to address the issue of availability of resources to engage in community schemes and aimed to make community ownership widely available for renewable energy developments. A voluntary scheme was encouraged led by the "shared ownership taskforce" (DECC, 2015b), a consultation group including commercial developers and representatives of community organisations. The UK Government stated that if this approach failed, the provision of shared ownership would be made mandatory for any commercial development (DECC, 2015a).

In Scotland, by contrast, the Scottish Government (2018) has recommended, since 2015, that developers offer shared ownership for all renewable energy projects above $50 \mathrm{~kW}$. This position has been further strengthened by a communication by Scotland's chief planner, John McNairney (2015), who, in a letter addressed to the heads of planning at Scottish planning authorities in November 2015, stressed the significance of shared ownership. Although shared ownership does not form part of the material considerations in determining the acceptability of a project in planning terms, it is nevertheless important because the economic and socio-economic impacts of a project are relevant material considerations.

In conclusion, while a growing number of policymakers now understand the importance of community benefits and community ownership, a number of ambiguities remain regarding both the policy discourse and national legislation concerning these schemes. A clear policy choice that makes community benefits and the provision of shared ownership schemes mandatory for each renewable energy project would help in making renewable developments more acceptable, and in enabling a positive role for citizens in the energy transition.

National legislation making community and shared ownership schemes mandatory would also support an energy justice policy approach based on the tenets of distributional and procedural justice (McCauley et al., 2013), thereby advancing an egalitarian view of energy policy (Pellegrini-Masini, 2019; PellegriniMasini et al., 2020).

\section{References}

Batel, S. and Devine-Wright, P. 2015. Towards a better understanding of people's responses to renewable energy technologies: Insights from social representations theory. Public Understanding of Science, 24, 311-325.

Bauwens, T., Gotchev, B. and Holstenkamp, L. 2016. What drives the development of community energy in Europe? The case of wind power cooperatives. Energy Research and Social Science, 13, 136-147.

Bell, D., Gray, T., Haggett, C. and Swaffield, J. 2013. Re-visiting the "social gap": Public opinion and relations of power in the local politics of wind energy. Environmental Politics, 22, 115-135. 
De Groot, J. I. and Steg, L. 2009. Mean or green: Which values can promote stable pro-environmental behavior? Conservation Letters, 2, 61-66.

DECC. 2011. Renewable energy roadmap. Department of Energy and Climate Change, London. Available at: www.gov.uk/government/publications/renewable-energy-roadmap.

DECC. 2014. Community energy strategy. Department of Energy and Climate Change, London. Available at: www.gov.uk/government/uploads/system/uploads/attachment data/file/275163/20140126Community_Energy_Strategy.pdf.

DECC. 2015a. Community energy strategy: Update. Department of Energy and Climate Change, London. Available at: www.gov.uk/government/uploads/system/uploads/ attachment_data/file/414446/CESU_FINAL.pdf.

DECC. 2015b. Government response to the Shared Ownership Taskforce. Department of Energy and Climate Change, London. Available at: www.gov.uk/government/publications/ government-response-to-the-shared-ownership-taskforce.

Diekmann, A. and Preisendörfer, P. 2003. Green and greenback: The behavioral effects of environmental attitudes in low-cost and high-cost situations. Rationality and Society, 15, 441-472.

European Parliament. 2018. Directive (EU) 2018/2001 of the European Parliament and of the Council of 11 December 2018 on the promotion of the use of energy from renewable sources. Official Journal of the European Union, 128, 83-206.

Haggett, C. and Aitken, M. 2015. Grassroots energy innovations: The role of community ownership and investment. Current Sustainable/Renewable Energy Reports, 2, 98-104.

Kalkbrenner, B. J. and Roosen, J. 2016. Citizens' willingness to participate in local renewable energy projects: The role of community and trust in Germany. Energy Research \& Social Science, 13, 60-70.

Lipp, J. and McMurtry, J. J. 2015. Benefits of renewable energy co-operatives: Summary of literature review from the Measuring the Co-operative Difference Research Network. Measuring the Co-operative Difference Research Network, Canada. Available at: http://ec.msvu.ca:8080/xmlui/handle/10587/1608.

Maslow, A. H. 1987. Motivation and personality. New York: Harper \& Row.

McCauley, D., Heffron, R. J., Stephan, H., Jenkins, K., Gillard, R., Snell, C. and Bevan, M. 2013. Advancing energy justice: The triumvirate of tenets and systems thinking. International Energy Law Review, 32, 107-110.

McNairney, J. 2015. Energy targets and Scottish planning policy. Local Government and Communities Directorate, Scottish Government, Edinburgh. Available at: www.gov. scot/publications/energy-targets-and-scottish-planning-policy-chief-planner-letter/.

Misztal, B. 2013. Trust in modern societies: The search for the bases of social order. Oxford: John Wiley \& Sons.

Pellegrini-Masini, G. 2007. The carbon-saving behaviour of residential households. Futures of Cities - 51st International Federation of Housing and Planning World Congress, 23-26 September 2007, Copenhagen.

Pellegrini-Masini, G. 2019. Energy equality and energy sufficiency: New policy principles to accelerate the energy transition. European Council for an Energy Efficient Economy 2019 Summer Study, "Energy efficiency first, but what next?", 3-8 June, Belambra Presqu'ile de Glens, France, 143-148.

Pellegrini-Masini, G., Pirni, A. and Maran, S. 2020. Energy justice revisited: A critical review on the philosophical and political origins of equality. Energy Research \& Social Science, 59, 101310. Available at: https://doi.org/10.1016/j.erss.2019.101310. 


\section{Theory of wind farm social acceptability}

Perlaviciute, G. and Steg, L. 2014. Contextual and psychological factors shaping evaluations and acceptability of energy alternatives: Integrated review and research agenda. Renewable and Sustainable Energy Reviews, 35, 361-381.

Scottish Government. 2018. Good practice principles for shared ownership of renewable energy developments. Energy and Climate Change Directorate, Edinburgh. Available at: www.gov.scot/binaries/content/documents/govscot/publications/consultation-paper/ 2018/11/consultation-scottish-government-good-practice-principles-shared-ownershiprenewable-energy-developments/documents/scottish-government-good-practice-principlesshared-ownership-renewable-energy-developments/scottish-government-good-practiceprinciples-shared-ownership-renewable-energy-developments/govscot\%3Adocument/ 00543554.pdf.

Slee, B. 2015. Is there a case for community-based equity participation in Scottish on-shore wind energy production? Gaps in evidence and research needs. Renewable and Sustainable Energy Reviews, 41, 540-549.

Steg, L., Bolderdijk, J. W., Keizer, K. and Perlaviciute, G. 2014. An integrated framework for encouraging pro-environmental behaviour: The role of values, situational factors and goals. Journal of Environmental Psychology, 38, 104-115.

Taormina, R. J. and Gao, J. H. 2013. Maslow and the motivation hierarchy: Measuring satisfaction of the needs. American Journal of Psychology, 126, 155-177.

Toke, D. 2005. Explaining wind power planning outcomes: Some findings from a study in England and Wales. Energy Policy, 33, 1527-1539.

van der Horst, D. and Toke, D. 2010. Exploring the landscape of wind farm developments: Local area characteristics and planning process outcomes in rural England. Land Use Policy, 27, 214-221.

van Veelen, B. and Haggett, C. 2016. Uncommon ground: The role of different place attachments in explaining community renewable energy projects. Sociologia Ruralis, $57,533-554$.

Walker, B. J. A., Wiersma, B. and Bailey, E. 2014. Community benefits, framing and the social acceptance of offshore wind farms: An experimental study in England. Energy Research and Social Science, 3, 46-54.

Warren, C., Lumsden, C., O’Dowd, S. and Birnie, R. 2005. "Green on green”: Public perceptions of wind power in Scotland and Ireland. Journal of Environmental Planning and Management, 48, 853-875. 


\section{Conclusions}

equality, not only because this could be argued to be morally desirable (PellegriniMasini et al., 2020) but because they appear to motivate citizens towards acceptance and participation (Drews and van den Bergh, 2016).

Finally, holding together procedural justice and fairness while shaping energy policy related benefits and costs in order to build extrinsic motivations (along with intrinsic ones) leads to the choice of implementing distributionally just policies which would favour the many over the few. Energy equality along with energy sufficiency (Pellegrini-Masini, 2019) will need to drive the transition if the current energy injustices, often related to economic inequality at the global level (Gore, 2015) and within countries (Galvin and Sunikka-Blank, 2018; Galvin, 2019), are to be addressed. Distributional justice policies leading towards more egalitarian societies will most likely support a per capita decrease in carbon emissions in high-income countries (Jorgenson et al., 2016; Knight et al., 2017), and might increase pro-environmental behaviours (Carlisle and Smith, 2005; Wilkinson and Pickett, 2010), while increasing quality of life in general (Wilkinson et al., 2010). In this respect, citizens' support for community benefit schemes and the co-operative model of shared ownership of wind farms confirmed in this research supports the idea that distributionally just energy policies at the community level (and beyond) are both desirable and necessary.

\section{References}

Carlisle, J. and Smith, E. R. 2005. Postmaterialism vs. egalitarianism as predictors of energy-related attitudes. Environmental Politics, 14, 527-540.

Drews, S. and van den Bergh, J. C. J. M. 2016. What explains public support for climate policies? A review of empirical and experimental studies. Climate Policy, 16, 855-876.

European Union. 2019. Clean energy for all Europeans. Directorate-General for Energy, Luxembourg. Available at: https://publications.europa.eu/en/publication-detail/-/publication/ b4e46873-7528-11e9-9f05-01aa75ed71a1/language-en.

Frey, B. S. 1999. Morality and rationality in environmental policy. Journal of Consumer Policy, 22, 395-417.

Galvin, R. 2019. Letting the Gini out of the fuel poverty bottle? Correlating cold homes and income inequality in European Union countries. Energy Research and Social Science, 58, 101255. Available at: https://doi.org/10.1016/j.erss.2019.101255.

Galvin, R. and Sunikka-Blank, M. 2018. Economic inequality and household energy consumption in high-income countries: A challenge for social science based energy research. Ecological Economics, 153, 78-88.

Geels, F. W. 2005. Processes and patterns in transitions and system innovations: Refining the co-evolutionary multi-level perspective. Technological Forecasting \& Social Change, 72, 681-696.

Gore, T. 2015. Extreme carbon inequality: Why the Paris climate deal must put the poorest, lowest emitting and most vulnerable people first. Oxfam International, Oxford. Available at: www.oxfam.org/sites/www.oxfam.org/files/file_attachments/mb-extremecarbon-inequality-021215-en.pdf.

Grin, J., Rotmans, J. and Schot, J. 2010. Transitions to sustainable development: New directions in the study of long term transformative change. Abingdon, UK: Routledge. 
Guruswamy, L. 2010. Energy justice and sustainable development. Colorado Journal of International Environmental Law and Policy, 21, 231-275.

Huijts, N. M. A., Molin, E. J. E. and Steg, L. 2012. Psychological factors influencing sustainable energy technology acceptance: A review-based comprehensive framework. Renewable and Sustainable Energy Reviews, 16, 525-531.

Jagers, S. C., Löfgren, Å. and Stripple, J. 2010. Attitudes to personal carbon allowances: Political trust, fairness and ideology. Climate Policy, 10, 410-431.

Jorgenson, A. K., Schor, J. B., Knight, K. W. and Huang, X. 2016. Domestic inequality and carbon emissions in comparative perspective. Sociological Forum, 31, 770-786.

Knight, K. W., Schor, J. B. and Jorgenson, A. K. 2017. Wealth inequality and carbon emissions in high-income countries. Social Currents, 4, 403-412.

McCauley, D., Heffron, R. J., Stephan, H., Jenkins, K., Gillard, R., Snell, C. and Bevan, M. 2013. Advancing energy justice: The triumvirate of tenets and systems thinking. International Energy Law Review, 32, 107-110.

Pellegrini-Masini, G. 2007. The carbon-saving behaviour of residential households Futures of Cities - 51st International Federation of Housing and Planning World Congress, 23-26 September 2007, Copenhagen.

Pellegrini-Masini, G. 2019. Energy equality and energy sufficiency: New policy principles to accelerate the energy transition. European Council for an Energy Efficient Economy 2019 Summer Study, "Energy efficiency first, but what next?", 3-8 June, Belambra Presqu'ile de Glens, France, 143-148.

Pellegrini-Masini, G. and Leishman, C. 2011. The role of corporate reputation and employees' values in the uptake of energy efficiency in office buildings. Energy Policy, 39, 5409-5419.

Pellegrini-Masini, G., Macsinga, I., Albulescu, P., Löfström, E., Sulea, C., Dumitru, A. and Nayum, A. 2019. D6.1 Report on social innovation drivers, barriers, actors and network structures (H2020 Project SMARTEES Grant Agreement No. 763912). Trondheim, Norway.

Pellegrini-Masini, G., Pirni, A. and Maran, S. 2020. Energy justice revisited: A critical review on the philosophical and political origins of equality. Energy Research \& Social Science, 59, 101310. Available at: https://doi.org/10.1016/j.erss.2019.101310.

Perlaviciute, G. and Steg, L. 2014. Contextual and psychological factors shaping evaluations and acceptability of energy alternatives: Integrated review and research agenda. Renewable and Sustainable Energy Reviews, 35, 361-381.

Sovacool, B. K., Heffron, R. J., McCauley, D. and Goldthau, A. 2016. Energy decisions reframed as justice and ethical concerns. Nature Energy, 1, 16024.

Steg, L., Bolderdijk, J. W., Keizer, K. and Perlaviciute, G. 2014. An integrated framework for encouraging pro-environmental behaviour: The role of values, situational factors and goals. Journal of Environmental Psychology, 38, 104-115.

Walker, G., Devine-Wright, P., Hunter, S., High, H. and Evans, B. 2010. Trust and community: Exploring the meanings, contexts and dynamics of community renewable energy. Energy Policy, 38, 2655-2663.

Wilkinson, R. G. and Pickett, K. 2010. The spirit level: Why greater equality makes societies stronger. New York: Bloomsbury.

Wilkinson, R., Pickett, K. and De Vogli, R. 2010. Equality, sustainability, and quality of life. The BMJ, 341, 1138-1140.

World Energy Council. 2019. World energy trilemma index report 2019. World Energy Council, London. Available at: www.worldenergy.org/assets/downloads/ WETrilemma_2019_Full_Report_v4_pages.pdf. 
16 Have you ever thought about any possible link between opposition or support and local ownership of a wind farm?

If not clear to the interviewee, it was rephrased as follows:

Do you think that local ownership of wind farms may influence levels of opposition or support for wind farms? How?

17 Wind turbines are sometimes controversial and local opposition is often present. Could the local ownership of the wind farm with its revenue put back into the local community compensate for the perception of local negative consequences of a wind farm, such as noise and visual impact?

\section{IV-Perception of factors influencing participation in community owned co-operatives}

This question aimed to answer research question 2: "Which factors influence participation in farm cooperatives? How are they related to one another?".

18 Have you ever discussed in your group/organisation/institution what could motivate or prevent local residents to purchase shares in a local co-operative wind farm? What do you think about it?

It was impossible to prompt all the factors raised in the literature review; therefore, leaving the question completely open appeared to be the most reasonable choice.

\section{Note}

1 During the development of the research project it was decided not to pursue this research question further. 